\title{
Effects of experimental reheating of natural basaltic ash at different temperatures and redox conditions
}

C. D’Oriano ${ }^{1}$, M. Pompilio ${ }^{1}$-, A. Bertagnini ${ }^{1}$, R. Cioni ${ }^{1,2}$ and M. Pichavant ${ }^{3,4}$

(1)

Sezione di Pisa, Istituto Nazionale di Geofisica e Vulcanologia, Via della Faggiola 32, 56126 Pisa, Italy

(2)

Dipartimento di Scienze Chimiche e Geologiche, Via Trentino 51, 09127 Cagliari, Italy

(3)

Université d'Orléans and CNRS/INSU, ISTO, UMR 7327, 45071 Orléans, France

(4)

BRGM, ISTO, UMR 7327, BP 36009, 45060 Orléans, France

\begin{abstract}
A set of experiments have been performed on volcanic materials from Etna, Stromboli and Vesuvius in order to evaluate how the exposure to thermal and redox conditions close to that of active craters affects the texture and composition of juvenile pyroclasts. Selected samples were placed within a quartz tube, in presence of air or under vacuum, and kept at $\mathrm{T}$ between 700 and $1,130{ }^{\circ} \mathrm{C}$, for variable time (40 min to $12 \mathrm{~h}$ ). Results show that reheating reactivates the melt, which, through processes of chemical and thermal diffusion, reaches new equilibrium conditions. In all the experiments performed at $\mathrm{T}=700-750{ }^{\circ} \mathrm{C}$, a large number of crystal nuclei and spherulites grows in the groundmass, suggesting conditions of high undercooling. This process creates textural heterogeneities at the scale of few microns but only limited changes of groundmass composition, which remains clustered around that of the natural glasses. Reheating at $\mathrm{T}=1,000-1,050{ }^{\circ} \mathrm{C}$ promotes massive groundmass crystallization, with a different mineral assemblage as a function of the redox conditions. Morphological modifications of clasts, from softening to sintering as temperature increases, occur under these conditions, accompanied by progressive smoothing of external surfaces, and a reduction in size and abundance of vesicles, until the complete obliteration of the preexisting vesicularity. The transition from sintering to welding, characteristic of high temperature, is influenced by redox conditions. Experiments at $\mathrm{T}=1,100-1,130{ }^{\circ} \mathrm{C}$ and under vacuum produce groundmass textures and glass compositions similar to that of the respective starting material. Collapse and welding of the clasts cause significant densification of the whole charge. At the same temperature, but in presence of air, experimental products at least result sintered and show holocrystalline groundmass. In all experiments, sublimates grow on the external surfaces of the clasts or form a lining on the bubble walls. Their shape and composition is a function of temperature and $\mathrm{fO}_{2}$ and the abundance of sublimates shows a peak at $1,000{ }^{\circ} \mathrm{C}$. The identification of the features recorded by pyroclasts during complex heating-cooling cycles allows reconstructing the complete clasts history before their final emplacement, during weakly explosive volcanic activity. This has a strong implication on the characterization of primary juvenile material and on the interpretation of eruption dynamics.
\end{abstract}


Keywords :

Volcanic ash Basalts Etna Stromboli Vesuvius Alteration Crystallization Experiments Reheating

\section{Introduction}

Weakly explosive eruptions produce a large range of volcanic products varying from bombs to fine ash (Cioni et al. 2010). Depending on the energy of each eruption, a large portion of these ejecta falls back into the vent or in the crater area where they are exposed to physicochemical conditions that are close to magmatic (Fig. 1). These products can be ejected by subsequent explosions until the final deposition outside the vent area occurs.

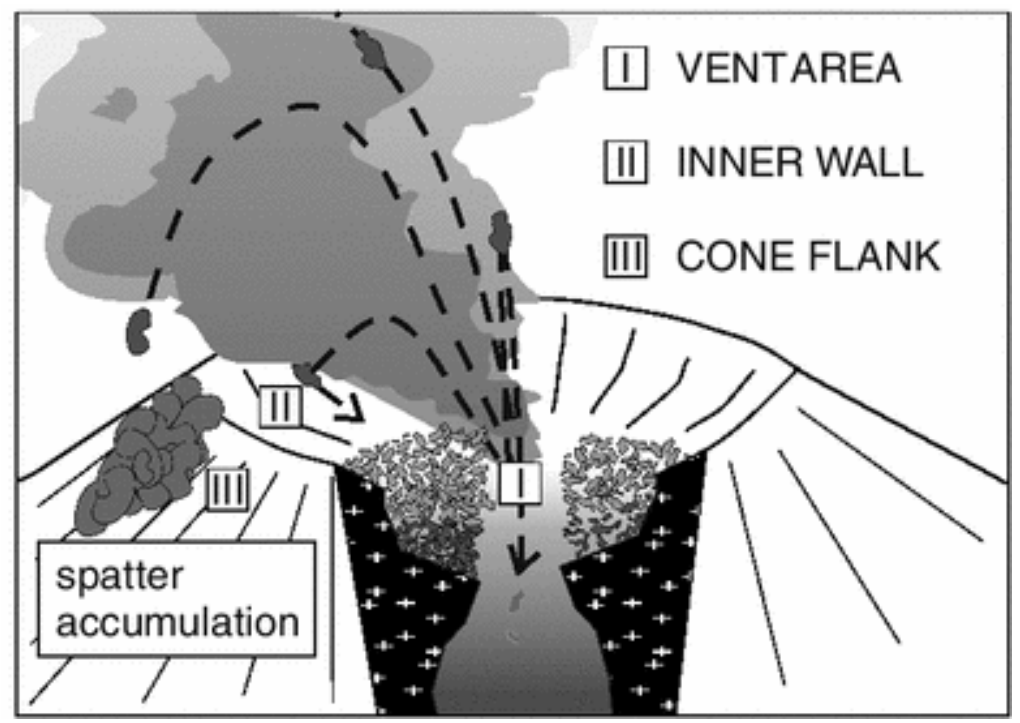

Fig. 1 : Cartoon of an idealized intracrater environment

Repeated cycles of cooling and reheating can induce substantial modifications of juvenile material, which superimpose on primary textural and compositional information.

Several experimental works have focused in the past on the processes of melting and crystallization at different cooling rates and variable redox conditions (see review of Hammer 2008 and references therein). Effects of reheating and alteration due to the superposition of lava lobes have also been successfully investigated through laboratory experiments by Burkhard $(2001,2002)$ on Hawaiian basalts. Mechanisms of oxidation of basaltic glass have been experimentally studied by Cooper et al. (1996). Laboratory reheating of pyroclasts have been carried out by Tait et al. (1998) and Moriizumi et al. (2008) to constrain cooling rate, and kinetics of iron oxidation processes by means of quantitative color measurements and magnetic mineralogy. Quane and Russell (2005), Quane et al. (2009) and Kennedy et al. (2010) performed high-T experiments on rhyolitic glass in order to study the processes, and the related timescales, of welding and compaction of porous volcanic materials. Their results proved useful for interpretation of the textures found in natural welded pyroclastic deposits (i.e., ignimbrites), and thus constraining the conditions for efficient compaction and sintering of pyroclastic materials (Grunder and Russell 2005). However with the exception of Spadaro et al. (2002) who exposed natural ash for variable time to low temperature fumaroles and gas on the Etna summit crater, little is known about the intracrater modifications of pyroclastic material at high temperature and variable oxygen fugacity. To fill this gap, we performed a series of experiments on juvenile glassy fragments with composition ranging from basalt to 
phonotephrite from three different Italian active volcanoes: Etna, Stromboli and Vesuvius. Although exposition to variable gas conditions, typical of the volcano conduit system can be hardly reproduced in a laboratory, reheating experiments of pyroclasts under different redox conditions can be easily performed in a vertical tube furnace. We report how external morphology, texture, color and composition of natural samples change as a consequence of variable times of exposition at different experimental temperatures and redox conditions, and discuss some general implications on processes that occur in crater area of active volcanoes.

\section{Starting rocks}

Glassy, medium (millimeter-sized) lapilli and scoriae from well-known eruptions of Etna, Stromboli and Vesuvius were selected as starting rocks (Table 1). Etna and Stromboli samples were collected immediately after (days/week) the eruption, in order to prevent postemplacement weathering. Vesuvius tephra represents the inner portion of a lapilli bed, not exposed to weathering agents.

Table 1

Bulk compositions of starting rocks

\begin{tabular}{|c|c|c|c|c|}
\hline \multirow{2}{*}{ Starting rocks wt $\%$} & Piazzola* & STPL2bis** (HP) & ST305*** (LP) & \multirow{2}{*}{\begin{tabular}{|l} 
VSM5*** \\
Vesuvius
\end{tabular}} \\
\hline & Etna & \multicolumn{2}{|l|}{ Stromboli } & \\
\hline $\mathrm{SiO}_{2}$ & 46.62 & 50.44 & 49.01 & 49.12 \\
\hline $\mathrm{TiO}_{2}$ & 1.78 & 0.93 & 0.90 & 0.75 \\
\hline $\mathrm{Al}_{2} \mathrm{O}_{3}$ & 17.32 & 17.06 & 17.53 & 15.66 \\
\hline $\mathrm{Fe}_{2} \mathrm{O}_{3 \text { (tot) }}$ & 12.16 & 8.97 & 8.76 & 6.69 \\
\hline $\mathrm{MnO}$ & 0.19 & 0.16 & 0.15 & 0.14 \\
\hline $\mathrm{MgO}$ & 5.24 & 6.09 & 6.34 & 4.84 \\
\hline $\mathrm{CaO}$ & 10.77 & 11.52 & 11.96 & 9.37 \\
\hline $\mathrm{Na}_{2} \mathrm{O}$ & 3.48 & 2.51 & 2.41 & 2.84 \\
\hline $\mathrm{K}_{2} \mathrm{O}$ & 1.91 & 2.12 & 1.86 & 7.12 \\
\hline $\mathrm{P}_{2} \mathrm{O}_{5}$ & 0.43 & 0.56 & 0.55 & 0.62 \\
\hline LOI & 0.75 & -0.19 & 0.40 & 1.54 \\
\hline Tot. & 100.65 & 100.17 & 99.87 & 98.69 \\
\hline
\end{tabular}


* Average of 3 analyses of distinct samples erupted during the fire fountain of January 5, 1990 (from Carveni et al. 1994), measured by XRF

** Measured by ICP-OES at the Activation Laboratories Ltd, Ancaster, Canada

*** Average of 6 analyses of distinct LP samples erupted during April 5, 2003, paroxysm (from Pompilio et al. 2012) measured by ICP-OES at the Centre de Recherches Petrographiques et Geochimiques (CRPG-SARM) in Nancy (France) following methods described in Carignan et al. (2001)

\section{Mt. Etna}

The sample (Piazzola) represents a proximal fallout deposit related to the January 5, 1990, fire fountain episode (Carveni et al. 1994). This tephra consists of scoriaceous highly vesicular, glassy lapilli with euhedral phenocrysts $(\approx 20-30 \mathrm{vol} \%)$ of plagioclase $(\mathrm{pl})$, clinopyroxene (cpx) and olivine (ol) and microphenocrysts of same minerals plus titano-magnetite (Ti-mag). Bulk rock composition is trachybasaltic, whereas groundmass glass attains phonotephritic composition $\left(\mathrm{SiO}_{2}\right.$ : 48.5-50.5 wt \%; alkali: 8.1-8.9 wt\%) (Fig. 2; Table 1). Groundmass glass is nearly anhydrous $\left(\mathrm{H}_{2} \mathrm{O}<1 \mathrm{wt} \%\right)$ as estimated by the difference method from EPMA analyses (Devine et al. 1995; Table 2). NBO/T (non-bridging oxygen per tetrahedron) (Mysen 1983) for the melt is 0.50 (Table 2) with a calculated (Giordano et al. 2005) glass transition temperature $\left(\mathrm{T}_{\mathrm{g}}\right)$ of $664{ }^{\circ} \mathrm{C}$.



Fig. 2 : Average bulk rocks (black symbols) and matrix glasses (open symbols) compositions plotted in the total alkalis versus silica diagram (Le Bas et al. 1986). circle PZ; diamond STASH-LP; square STASH-HP; triangle VES 

Table 2

Average glass composition measured in the starting material

\begin{tabular}{|c|c|c|c|c|c|c|c|c|c|c|c|c|c|c|c|c|c|}
\hline \multicolumn{2}{|c|}{ g rock } & \multirow{2}{*}{\begin{tabular}{|l}
$\mathbf{S i O}_{\mathbf{2}}$ \\
49.46
\end{tabular}} & \multirow{2}{*}{\begin{tabular}{|l}
$\mathbf{T i O}_{2}$ \\
1.97
\end{tabular}} & \multirow{2}{*}{\begin{tabular}{|l|}
$\mathbf{A l}_{2} \mathbf{O}_{3}$ \\
16.53 \\
\end{tabular}} & \multirow{2}{*}{\begin{tabular}{|l}
$\mathbf{F e O}_{\text {tot }}$ \\
10.07
\end{tabular}} & \multirow{2}{*}{\begin{tabular}{|l|} 
MnO \\
0.23
\end{tabular}} & \multirow{2}{*}{\begin{tabular}{|l|} 
MgO \\
3.74
\end{tabular}} & \multirow{2}{*}{\begin{tabular}{|l|}
$\mathbf{C a O}$ \\
8.08
\end{tabular}} & \multirow{2}{*}{\begin{tabular}{|l}
$\mathrm{Na}_{2} \mathrm{O}$ \\
5.12 \\
\end{tabular}} & \multirow{2}{*}{\begin{tabular}{|l}
$\mathbf{K}_{\mathbf{2}} \mathbf{O}$ \\
3.31
\end{tabular}} & \multirow{2}{*}{$\begin{array}{l}\mathbf{P}_{2} \mathbf{O}_{5} \\
0.93\end{array}$} & \multirow{2}{*}{\begin{tabular}{|l|} 
Tot \\
99.45
\end{tabular}} & \multirow{2}{*}{\begin{tabular}{|l}
$\mathrm{Fe}_{2} \mathrm{O}_{3}$ \\
2.64
\end{tabular}} & \multirow{2}{*}{\begin{tabular}{|l|} 
FeO \\
7.70
\end{tabular}} & \multirow{2}{*}{\begin{tabular}{|l|}
$\mathbf{N B O} / \mathbf{T}$ \\
0.50
\end{tabular}} & \multirow{2}{*}{ 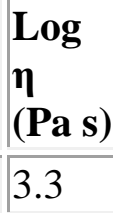 } & \multirow{2}{*}{$\frac{\mid \begin{array}{l}\mathbf{T}_{\mathbf{g}} \\
\left({ }^{\circ} \mathbf{C}\right)\end{array}}{664}$} \\
\hline \multirow[b]{2}{*}{ Piazzola } & Mean & & & & & & & & & & & & & & & & \\
\hline & $\begin{array}{l}\sigma \\
(\mathrm{n}=12)\end{array}$ & 0.61 & 0.08 & 0.15 & 0.21 & 0.05 & 0.09 & 0.23 & 0.15 & 0.20 & 0.06 & & & & & & \\
\hline \multirow{2}{*}{$\begin{array}{l}\text { ST305 } \\
\text { (LP) }\end{array}$} & Mean & 50.67 & 1.04 & 16.89 & 8.44 & 0.17 & 5.73 & 10.87 & 2.64 & 2.46 & 0.70 & 99.62 & 2.19 & 6.48 & 0.55 & 2.2 & 672 \\
\hline & $\begin{array}{l}\sigma \\
(\mathrm{n}=21)\end{array}$ & 0.49 & 0.08 & 0.23 & 0.26 & 0.06 & 0.22 & 0.39 & 0.11 & 0.18 & 0.06 & & & & & & \\
\hline \multirow{2}{*}{$\begin{array}{l}\text { STPL2bis } \\
\text { (HP) }\end{array}$} & Mean & 52.24 & 1.62 & 15.55 & 10.00 & 0.22 & 3.69 & 7.64 & 3.33 & 4.03 & 1.15 & 99.48 & 2.82 & 7.47 & 0.45 & 2.7 & 673 \\
\hline & $\begin{array}{l}\sigma \\
(\mathrm{n}=10)\end{array}$ & 0.38 & 0.11 & 0.28 & 0.38 & 0.03 & 0.11 & 0.30 & 0.22 & 0.51 & 0.08 & & & & & & \\
\hline \multirow[b]{2}{*}{ VSM5 } & Mean & 48.69 & 0.85 & 17.87 & 8.10 & 0.20 & 2.92 & 7.37 & 4.95 & 5.78 & 0.67 & 97.38 & 2.71 & 5.66 & 0.41 & 3.9 & 663 \\
\hline & $\begin{array}{l}\sigma \\
(\mathrm{n}=28)\end{array}$ & 0.69 & 0.08 & 0.30 & 0.28 & 0.04 & 0.21 & 0.33 & 0.25 & 0.37 & 0.09 & & & & & & \\
\hline
\end{tabular}

$\sigma=$ standard deviation; $\mathrm{n}=$ number of analyses; $\mathrm{FeO}$ and $\mathrm{Fe}_{2} \mathrm{O}_{3}$ have been calculated on the basis of Sack et al. (1981) and considering the intrinsic $\mathrm{fO}_{2}$ (see text); NBO/T (non-bridging oxygen per tetrahedron) calculated following Mysen (1983) with $\mathrm{Si}, \mathrm{Ti}, \mathrm{Al}, \mathrm{Fe}{ }^{3+}$ and $\mathrm{P}$ as tetrahedrally coordinated cations; $\eta=$ viscosity calculated following Eq. 1 of Giordano et al. (2008) at eruptive temperature of $1,090{ }^{\circ} \mathrm{C}$ for Piazzola and STPL2bis, $1,130{ }^{\circ} \mathrm{C}$ for ST305 and $1,050{ }^{\circ} \mathrm{C}$ for VSM5 (see text for details); $\mathrm{T}_{\mathrm{g}}=$ temperature of glass transition, calculated with the model of Giordano et al. (2005) 


\section{Stromboli}

As starting rocks, we considered both a so-called "golden pumice" representing the deepseated and volatile-rich, low porphyricity (LP) magma and a dark scoria representing the shallow, degassed and high porphyricity magma (HP) (Bertagnini et al. 2008). LP pumice (ST305), erupted on April 5, 2003, paroxysm (Rosi et al. 2006), is glassy with 15-20 vol\% of crystals, most of which are xenocrysts testifying for the syn-eruptive mingling with the HP magma, while the original crystal content of the LP magma is lower ( $\leq 5 \mathrm{vol} \%$ of cpx and ol) (Francalanci et al. 2008). On the contrary, HP scoria (STPL2bis) erupted in October 2006 (Landi et al. 2011) contains 45-50 vol\% of euhedral pl, cpx and ol phenocrysts (Bertagnini et al. 2008).

The LP and HP bulk rocks are plotted in the field of basalt on the TAS diagram (Fig. 2; Table 1). Conversely, on the $\mathrm{SiO}_{2}-\mathrm{K}_{2} \mathrm{O}$ diagram (Peccerillo and Taylor 1976), LP rocks are plotted astride the boundary line between shoshonitic and $\mathrm{HK}$ basalts $\left(\mathrm{SiO}_{2}: 48.4-49.8 \mathrm{wt} \%\right.$; $\mathrm{K}_{2} \mathrm{O} 1.8-1.9$ wt\%) while HP rocks are $\mathrm{HK}$ shoshonitic basalts $\left(\mathrm{SiO}_{2}: 48.5-51.5\right.$ wt\%; $\mathrm{K}_{2} \mathrm{O}$ 1.9-2.5 wt\%) (Bertagnini et al. 2008). Groundmass glass composition in LP clasts is close to the bulk rock (Fig. 2; Tables 1,2), reflecting the low-crystal content of the magma, while HP glass strongly differs from the bulk rock, as a consequence of the high porphyricity of the products (Fig. 2; Table 2) (Francalanci et al. 2008; Métrich et al. 2005). LP glass has NBO/T values from 0.50 to 0.56 , and a calculated $\mathrm{T}_{\mathrm{g}}$ between 672 and $677^{\circ} \mathrm{C}$. NBO/T of HP glass is between 0.41 and 0.45 , while $\mathrm{T}_{\mathrm{g}}$ varies between 670 and $675^{\circ} \mathrm{C}$. The water content of $\mathrm{LP}$ pumice glass is $\leq 0.6 \mathrm{wt} \%$ (Métrich et al. 2010), while HP glass can be considered anhydrous.

\section{Vesuvius}

Selected juvenile material is from a lapilli bed of the violent strombolian activity occurred in the period between the AD 79 Pompeii eruption and the AD 472 Pollena eruption (Cioni et al. 2008), and consists mainly of highly vesicular pumice, with minor dark, highly crystallized scoria. Lapilli (VSM5) are glassy with phenocrysts of cpx, leucite (lct) and rare phlogopite (phl), and microlites of cpx, lct and $\mathrm{pl}$ and rare oxides. Bulk rock has a phonotephritic composition $\left(\mathrm{SiO}_{2}: 50.6 \mathrm{wt} \%\right.$, total alkali: $\left.10.2 \mathrm{wt} \%\right)$, and matrix glass is fairly homogeneous (on average $\mathrm{SiO}_{2}: 48.7 \mathrm{wt} \%$, total alkali: $10.7 \mathrm{wt} \%$ ) (Fig. 2; Tables 1, 2). Glass NBO/T ranges between 0.37 and 0.43 , and the calculated $\mathrm{T}_{\mathrm{g}}$ is between 656 and $669^{\circ} \mathrm{C}$. Glass can be considered nearly anhydrous.

\section{Experimental rationale}

Starting pyroclasts were crushed in a nylon mortar in order to expose the inner pristine portions of the sample (Fig. 3). Natural samples, in fact, though fresh, could have suffered some alteration during and after eruption, with subsequent modification of their external surfaces. The mechanically fragmented material, a sort of artificial ash, was then sieved and the fraction from the size interval $1-0.71 \mathrm{~mm}$ selected. 

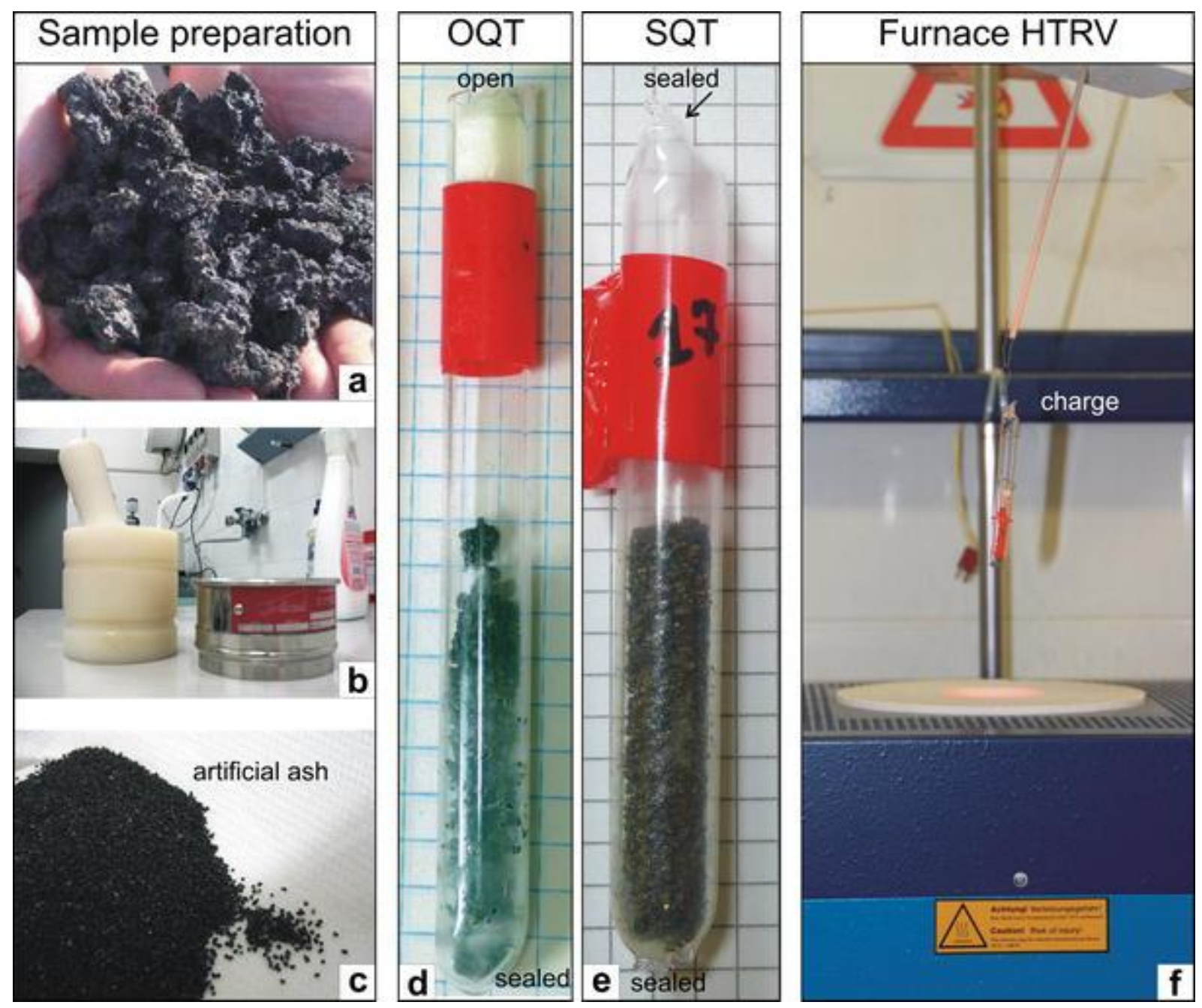

Fig. 3

Sample preparation, experimental set-upsetup and instrument. Natural scoria bomb (a) was crushed (b) and sieved (c) in the ash fraction size range. Two types of experiments were performed: (d) in OQT (open quartz tube) and (e) in SQT (sealed quartz tube) redox conditions. The charge was then suspended with Kanthal wires in the INGV-Pisa HTRV vertical furnace at $1 \mathrm{~atm}$ of pressure (f) 
Artificial ash was dried at $110{ }^{\circ} \mathrm{C}$ in an oven for more than $12 \mathrm{~h}$. A few grams of dry ash were introduced in a vessel formed by a fused quartz tube segment $(8-10 \mathrm{~cm}$ of length, $10 \mathrm{~mm}$ of diameter). Two different experimental setups were prepared: (a) OQT: open quartz tube to air from one side (Fig. 3d) and (b) SQT: sealed quartz tube at both sides, after air evacuation with a vacuum pump (Fig. 3e). The sample vessels were suspended with Kanthal wires in a Gero ${ }^{\mathrm{TM}}$ HTRV 70-250/16 vertical MoSi resistance furnace at atmospheric pressure (Fig. 3f). The extent of the hot zone in the furnace is about $10 \mathrm{~cm}$, with a temperature gradient of less than $9{ }^{\circ} \mathrm{C}$ at low temperatures and less than $3{ }^{\circ} \mathrm{C}$ at $\mathrm{T}>1,000{ }^{\circ} \mathrm{C}$. The effective temperature at the sample position was checked before and after each run with a type $\mathrm{S}$ thermocouple $\left(1.5{ }^{\circ} \mathrm{C}\right.$ standard error). Accuracy of thermocouple was checked against the melting point of pure gold $\left(1,069^{\circ} \mathrm{C}\right)$.

Three sets of experiments corresponding to three temperature intervals were performed: 700 $750,1,000-1,100$ and $1,094-1,130{ }^{\circ} \mathrm{C}$ (Table 3). The highest temperature range $(1,000$ $1,130{ }^{\circ} \mathrm{C}$ ) used in the experiments compares with the eruptive temperature for the studied samples, as measured at Etna (Calvari et al. 1994; Pompilio et al. 1998) or estimated for Vesuvius (Cioni et al. 1999). For Stromboli, an eruptive temperature of $1,091{ }^{\circ} \mathrm{C}$ was measured on an active lava flow during the 2002-2003 eruption (Coltelli, personal communication), but we extended the experiments up to $1,130{ }^{\circ} \mathrm{C}$, which corresponds to the temperature of homogenization determined on melt inclusions hosted in olivines (Métrich et al. 2001). The lower range of reference temperatures $\left(700-750{ }^{\circ} \mathrm{C}\right)$ for the experiments roughly corresponds to the thermal conditions induced by passive degassing through a porous crater infilling, as measured for the Stromboli crater by Allard et al. (2008). These temperatures are higher than $\mathrm{T}_{\mathrm{g}}$ of the melt calculated on the basis of the composition of glasses used in the experiments (Dingwell and Webb 1990; Giordano et al. 2005), allowing the investigation of late stages of groundmass crystallization, vesiculation due to second boiling and sintering of clasts. 

Table 3

Experimental conditions, groundmass texture and composition and related rheological parameters

\begin{tabular}{|c|c|c|c|c|c|c|c|c|c|c|}
\hline RUN\# & $\begin{array}{l}\text { Starting } \\
\text { material }\end{array}$ & $\begin{array}{l}\text { Duration } \\
\text { (min) }\end{array}$ & $\begin{array}{l}\text { Experimental T } \\
\left({ }^{\circ} \mathbf{C}\right)\end{array}$ & $\begin{array}{l}\text { Type of } \\
\text { experiment }\end{array}$ & $\begin{array}{l}\text { Groundmass } \\
\text { texture }\end{array}$ & $\begin{array}{l}\text { Groundmass } \\
\text { composition (wt \%) }\end{array}$ & $\mathrm{SiO}_{2}$ & $\mathrm{TiO}_{2}$ & $\mathrm{Al}_{2} \mathrm{O}_{3}$ & $\mathrm{FeO}_{\text {tot }}$ \\
\hline \multirow[t]{2}{*}{ PZ15 } & Piazzola & 70 & 736 & OQT & Glassy & Mean & 50.23 & 2.16 & 16.80 & 10.29 \\
\hline & & & & & & $\sigma(n=6)$ & 0.16 & 0.07 & 0.11 & 0.28 \\
\hline \multirow{2}{*}{ PZ29 } & Piazzola & 978 & 761 & SQT & Glassy & Mean & 50.55 & 2.18 & 16.98 & 10.44 \\
\hline & & & & & & $\sigma(\mathrm{n}=7)$ & 0.39 & 0.19 & 0.19 & 0.38 \\
\hline PZ1 & Piazzola & 41 & 1,013 & OQT & Holocrystalline & n.m. & & & & \\
\hline PZ2 & Piazzola & 81 & 1,014 & OQT & Holocrystalline & n.m. & & & & \\
\hline PZ3 & Piazzola & 175 & 1,012 & OQT & Holocrystalline & n.m. & & & & \\
\hline PZ16 & Piazzola & 180 & 1,007 & SQT & Holocrystalline & n.m. & & & & \\
\hline \multirow{4}{*}{ PZ10 } & Piazzola & 229 & 1,101 & OQT & Hypocrystalline & Mean exposed to air & 56.02 & 1.45 & 17.63 & 4.46 \\
\hline & & & & & & $\sigma(\mathrm{n}=10)$ & 1.21 & 0.16 & 0.53 & 0.19 \\
\hline & & & & & & Mean inner tube & 54.58 & 2.34 & 16.51 & 5.38 \\
\hline & & & & & & $\sigma(n=6)$ & 0.48 & 0.04 & 0.17 & 0.21 \\
\hline \multirow{2}{*}{ PZ13 } & Piazzola & 180 & 1,102 & SQT & Glassy & Mean & 49.09 & 2.09 & 15.11 & 10.30 \\
\hline & & & & & & $\sigma(\mathrm{n}=66)$ & 1.55 & 0.09 & 0.65 & 0.39 \\
\hline \multirow{2}{*}{ STASH3 } & ST305 & 1,140 & 716 & SQT & Glassy & Mean & 50.58 & 0.96 & 17.03 & 8.87 \\
\hline & & & & & & $\sigma(\mathrm{n}=6)$ & 0.72 & 0.09 & 0.24 & 0.62 \\
\hline \multirow{2}{*}{ STASH1 } & ST305 & 660 & 752 & OQT & Glassy & Mean & 51.36 & 0.94 & 17.42 & 8.05 \\
\hline & & & & & & $\sigma(n=6)$ & 0.54 & 0.10 & 0.17 & 0.34 \\
\hline \multirow{2}{*}{ STASH9 } & ST305 & 120 & 1,007 & SQT & Hypocrystalline & Mean & 49.53 & 1.04 & 17.72 & 8.71 \\
\hline & & & & & & $\sigma(\mathrm{n}=8)$ & 0.72 & 0.15 & 0.36 & 0.83 \\
\hline STASH2 & ST305 & 80 & 1,000 & OQT & Holocrystalline & n.m. & & & & \\
\hline
\end{tabular}




\begin{tabular}{|c|c|c|c|c|c|c|c|c|c|c|}
\hline RUN\# & $\begin{array}{l}\text { Starting } \\
\text { material }\end{array}$ & $\begin{array}{l}\text { Duration } \\
\text { (min) }\end{array}$ & $\begin{array}{l}\text { Experimental T } \\
\left({ }^{\circ} \mathbf{C}\right)\end{array}$ & $\begin{array}{l}\text { Type of } \\
\text { experiment }\end{array}$ & $\begin{array}{l}\text { Groundmass } \\
\text { texture }\end{array}$ & $\begin{array}{l}\text { Groundmass } \\
\text { composition }(w t \%)\end{array}$ & $\mathrm{SiO}_{2}$ & $\mathbf{T i O}_{2}$ & $\mathrm{Al}_{2} \mathbf{O}_{3}$ & $\mathrm{FeO}_{\text {tot }}$ \\
\hline \multirow{2}{*}{ STASH4 } & St305 & 210 & 1,050 & SQT & Hypocrystalline & Mean & 56.39 & 1.52 & 14.67 & 5.45 \\
\hline & & & & & & $\sigma(\mathrm{n}=38)$ & 0.59 & 0.15 & 0.51 & 0.29 \\
\hline STASH11 & St305 & 100 & 1,050 & OQT & Holocrystalline & n.m. & & & & \\
\hline \multirow{2}{*}{ STASH10 } & St305 & 240 & 1,120 & SQT & Hypocrystalline & Mean & 56.03 & 0.93 & 16.64 & 4.47 \\
\hline & & & & & & $\sigma(\mathrm{n}=14)$ & 1.50 & 0.19 & 2.08 & 0.58 \\
\hline STASH7 & St305 & 210 & 1,130 & SQT & Hypocrystalline & n.a. & & & & \\
\hline \multirow{2}{*}{ STASH8 } & STPL2bis & 160 & 1,113 & SQT & Glassy & Mean & 51.71 & 1.59 & 15.28 & 10.07 \\
\hline & & & & & & $\sigma(\mathrm{n}=7)$ & 0.69 & 0.11 & 0.09 & 0.29 \\
\hline \multirow{2}{*}{ VES1 } & VSM5 & 1,260 & 713 & OQT & Glassy & Mean & 50.20 & 0.96 & 18.81 & 7.72 \\
\hline & & & & & & $\sigma(\mathrm{n}=7)$ & 0.56 & 0.08 & 0.42 & 0.49 \\
\hline \multirow{2}{*}{ VES3 } & VSM5 & 120 & 700 & SQT & Glassy & Mean & 49.94 & 1.00 & 19.02 & 7.82 \\
\hline & & & & & & $\sigma(\mathrm{n}=7)$ & 0.56 & 0.13 & 0.17 & 0.39 \\
\hline VES2 & VSM5 & 180 & 1,009 & OQT & Holocrystalline & n.m. & & & & \\
\hline VES8 & VSM5 & 105 & 1,008 & SQT & Holocrystalline & n.m. & & & & \\
\hline \multirow{2}{*}{ VES10 } & VSM5 & 100 & 1,094 & SQT & Glassy & Mean & 50.08 & 0.85 & 17.95 & 7.32 \\
\hline & & & & & & $\sigma(\mathrm{n}=32)$ & 0.41 & 0.11 & 0.33 & 0.38 \\
\hline \multirow{2}{*}{ VES11 } & VSM5 & 140 & 1,095 & OQT & Glassy & Mean & 51.44 & 0.84 & 18.19 & 5.27 \\
\hline & & & & & & $\sigma(\mathrm{n}=11)$ & 0.73 & 0.08 & 0.15 & 0.50 \\
\hline
\end{tabular}

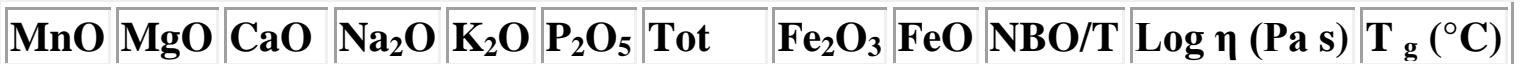

\begin{tabular}{|l|l|l|l|l|l|l|l|l|l|l|l|l|l|}
\hline 0.28 & 3.73 & 8.09 & 4.45 & 3.72 & nd & 99.75 & 11.40 & 0.03 & 0.17 & 9.7 & 675 \\
\hline 0.05 & 0.11 & 0.45 & 0.42 & 0.34 & & & & & & & \\
\hline 0.24 & 3.60 & 6.62 & 4.99 & 4.13 & nd & 99.73 & 2.77 & 7.94 & 0.42 & 8.9 & 670 \\
\hline
\end{tabular}




\begin{tabular}{|c|c|c|c|c|c|c|c|c|c|c|c|}
\hline MnO & MgO & $\mathrm{CaO}$ & $\mathrm{Na}_{2} \mathrm{O}$ & $\mathrm{K}_{2} \mathrm{O}$ & $\mathbf{P}_{2} \mathbf{O}_{5}$ & Tot & $\mathrm{Fe}_{2} \mathrm{O}_{3}$ & $\mathrm{FeO}$ & $\mathrm{NBO} / \mathrm{T}$ & $\log \eta(\operatorname{Pa} s)$ & $\mathbf{T}_{\mathrm{g}}\left({ }^{\circ} \mathbf{C}\right)$ \\
\hline 0.11 & 0.09 & 0.35 & 0.45 & 0.23 & & & & & & & \\
\hline 0.16 & 2.67 & 4.45 & 6.65 & 4.96 & 1.24 & 99.70 & 4.62 & 0.31 & 0.17 & 4.1 & 660 \\
\hline 0.05 & 0.32 & 0.46 & 0.46 & 0.19 & 0.16 & & & & & & \\
\hline 0.15 & 3.20 & 5.68 & 5.70 & 4.34 & 1.38 & 99.25 & 1.38 & 4.13 & 0.34 & 4.1 & 673 \\
\hline 0.04 & 0.12 & 0.20 & 0.15 & 0.08 & 0.07 & & & & & & \\
\hline 0.24 & 3.40 & 7.82 & 3.90 & 3.25 & 0.79 & 95.98 & 2.55 & 8.01 & 0.47 & 3.3 & 674 \\
\hline 0.05 & 0.28 & 0.32 & 0.44 & 0.15 & 0.08 & & & & & & \\
\hline 0.19 & 6.49 & 11.23 & 2.79 & 1.52 & 0.56 & 100.21 & 2.30 & 6.80 & 0.56 & 10.0 & 670 \\
\hline 0.03 & 0.27 & 0.59 & 0.14 & 0.31 & 0.05 & & & & & & \\
\hline 0.18 & 6.36 & 10.80 & 1.81 & 2.09 & 0.59 & 99.59 & 8.91 & 0.03 & 0.27 & 9.1 & 679 \\
\hline 0.04 & 0.06 & 0.90 & 0.80 & 0.36 & 0.06 & & & & & & \\
\hline 0.17 & 5.60 & 11.14 & 2.94 & 1.60 & 0.66 & 99.11 & 2.23 & 6.70 & 0.52 & 3.8 & 674 \\
\hline 0.05 & 0.69 & 0.96 & 0.23 & 0.60 & 0.18 & & & & & & \\
\hline 0.19 & 4.74 & 7.21 & 3.11 & 4.52 & 1.45 & 99.24 & 1.47 & 4.12 & 0.41 & 4.5 & 681 \\
\hline 0.04 & 0.40 & 0.47 & 0.25 & 0.42 & 0.12 & & & & & & \\
\hline 0.16 & 3.76 & 6.74 & 3.30 & 4.35 & 1.32 & 97.69 & 1.17 & 3.41 & 0.31 & 4.0 & 688 \\
\hline 0.04 & 0.63 & 0.95 & 0.22 & 0.61 & 0.26 & & & & & & \\
\hline 0.21 & 3.77 & 7.56 & 3.23 & 4.00 & 1.08 & 98.50 & 2.84 & 7.51 & 0.44 & 3.3 & 672 \\
\hline 0.03 & 0.05 & 0.13 & 0.19 & 0.17 & 0.04 & & & & & & \\
\hline 0.29 & 3.21 & 7.08 & 5.12 & 5.69 & nd & 99.08 & 8.57 & 0.01 & 0.17 & 10.4 & 669 \\
\hline 0.06 & 0.09 & 0.55 & 0.14 & 1.27 & & & & & & & \\
\hline 0.23 & 2.99 & 7.35 & 5.33 & 5.28 & nd & 98.96 & 2.60 & 5.48 & 0.36 & 10.5 & 671 \\
\hline 0.10 & 0.04 & 0.61 & 0.36 & 1.02 & & & & & & & \\
\hline
\end{tabular}




\begin{tabular}{|l|l|l|l|l|l|l|l|l|l|l|l|l|l|l|}
\hline $\mathbf{M n O}$ & $\mathbf{M g O}$ & $\mathbf{C a O}$ & $\mathbf{N a}_{2} \mathbf{O}$ & $\mathrm{K}_{2} \mathbf{O}$ & $\mathbf{P}_{2} \mathbf{O}_{5}$ & $\mathbf{T o t}$ & $\mathbf{F e}_{2} \mathbf{O}_{3}$ & $\mathbf{F e O}$ & $\mathbf{N B O} / \mathbf{T}$ & $\log \eta(\mathbf{P a ~ s})$ & $\mathbf{T}_{\mathbf{g}}\left({ }^{\circ} \mathbf{C}\right)$ \\
\hline 0.20 & 3.25 & 7.74 & 4.36 & 6.04 & 0.70 & 98.49 & 2.36 & 5.20 & 0.39 & 3.6 & 669 \\
\hline 0.03 & 0.16 & 0.24 & 0.14 & 0.21 & 0.07 & & & & & & \\
\hline 0.18 & 2.84 & 7.04 & 4.79 & 6.66 & 0.78 & 98.02 & 5.48 & 0.33 & 0.22 & 3.9 & 671 \\
\hline 0.05 & 0.23 & 0.39 & 0.20 & 0.35 & 0.05 & & & & & & \\
\hline
\end{tabular}

SQT sealed quartz tube, OQT open quartz tube, n.m. not measurable, n.a. not analyzed, $\sigma$ standard deviation, n number of analyses; FeO and $\mathrm{Fe}_{2} \mathrm{O}_{3}$ have been calculated on the basis of Sack et al. (1981) and considering the intrinsic $\mathrm{fO}_{2}$ (SQT) or that of the air (OQT); NBO/T and Tg have been calculated as in Table 2: $\log \eta$ is referred to the experimental temperature using an anhydrous glass composition 

For each temperature range, experiments were carried out in sealed (SQT) or open quartz tubes (OQT) in order to prevent or to allow for atmospheric oxidation (Table 3). Experimental samples were quenched in air and the measured rate of quenching (cooling) varies from $13{ }^{\circ} \mathrm{C} / \mathrm{s}$ (in the interval $1,130-750{ }^{\circ} \mathrm{C}$ ) to $3{ }^{\circ} \mathrm{C} / \mathrm{s}$ (in the interval $750-400{ }^{\circ} \mathrm{C}$ ).

Run times vary from 40 to $976 \mathrm{~min}$ (Table 3 ) reasonably approaching the duration of the interaction between pyroclasts and the environmental atmosphere during the course of lowintensity, pulsating eruptions.

While we did not measure the $\mathrm{fO}_{2}$ within the SQT vessel during the experiments, we assume that this parameter is close to the intrinsic oxygen fugacity of the three investigated natural magmas, estimated, respectively, to be NNO (nickel-nickel oxide) buffer for Etna (Métrich and Rutherford 1998) and $1 \log \mathrm{fO}_{2}$ units above $(\mathrm{NNO}+1)$ for Stromboli and Vesuvius (Di Carlo et al. 2006; Scaillet et al. 2008); in the OQT vessel, the oxygen fugacity can be considered close to that of air $\left(\mathrm{fO}_{2}=10^{-0.7}\right)$.

\section{Analytical methods}

Macroscopic, morphological, textural and compositional information on individual clasts, following the methods of Cioni et al. (2008) was collected on fragments before and after experimental runs. Macroscopic characterization of fragments includes observation of external color, overall shape, and vesicularity under an optical stereomicroscope. A set of 10 randomly selected ash fragments for each sample was considered for in-depth inspection of microscopic features. Clast 3D external shape was characterized by using a scanning electron microscope (SEM) working in secondary electron mode (at INGV of Pisa, Rome and Catania). Beside the overall shape, parameters used for the description of external morphology are the occurrence and extent of glass sintering (local disappearance of clastclast contacts), the shape and size of vesicles, the occurrence of secondary vesiculation, the presence of vapor-phase condensates, the crystallization of new microlites and the occurrence of surface cracks. The same fragments were then embedded in epoxy resin and polished until a surface approximately containing the maximum diameter of the fragments was exposed. These mounts were used for SEM inspection, backscattered electrons (BSE) imaging of the textural features (crystals and vesicles shapes and contents) and for analysis of the individual clasts. Major elements concentrations in glasses were determined at INGV-Roma with a JeolJXA8200 electron microprobe (EMP) equipped with five wavelength-dispersive spectrometers, using 15-kV accelerating voltage and 10-nA beam current. Analyses were performed with a defocused electron beam of 5-10 $\mu \mathrm{m}$, depending on available area, and a counting time of $5 \mathrm{~s}$ on background and $15 \mathrm{~s}$ on peak. Analyses of matrix glasses were performed on several clasts from each experiment.

\section{Results}

\section{Morphological and textural features}

\section{Starting material}

Fragments obtained after crushing have distinctive morphology and color depending on the volcano they came from (Fig. 4). Piazzola has bright black, smooth and fluidal external surfaces and moderately vesicular groundmass. LP portions of ST305 have a bright, light 
color and a highly vesicular, spongy aspect while the HP portions (ST305 and STPL2bis) are dark, with smooth, fluidal and vesicular surfaces and poorly vesicular groundmass. VSM5 mainly consists of dark brown, fluidal, moderately vesicular fragments.
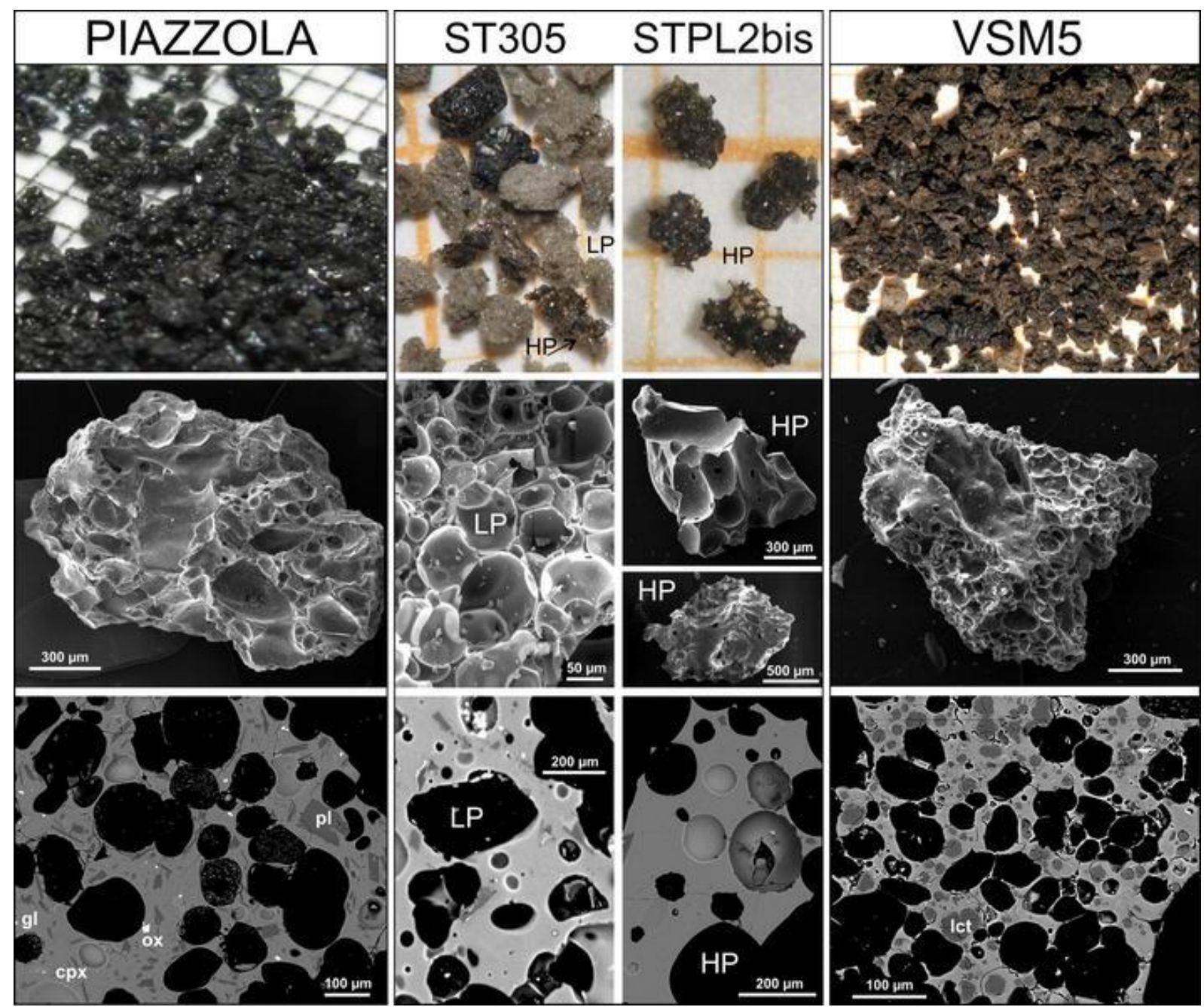

Fig. 4 : Color, morphological and textural features of artificial ash used as starting material for experiments. Very fine ( $<32$ micron) particles adhering to the clast surfaces are related to mechanical crushing during sample preparation. LP and HP are low and high porphyritic magmas, respectively; gl glass, cpx clinopyroxene, ox oxide, pl plagioclase, lct leucite

In all samples, the external surfaces are glassy and virtually free of vapor-phase condensates or secondary minerals (Fig. 4). Thin section inspection reveals that matrix glass is hyaline, and contains mainly rounded bubbles; some vesicles have a polylobate shape, resulting from coalescence. Variable contents of microphenocrysts/microlites of different types are present in groundmass: pl, cpx, minor ol and Ti-mag in Piazzola; rare pl in ST305 and STPL2bis; lct, subordinate cpx and $\mathrm{pl}$ and rare oxides in VSM5. 


\section{Experimental ash}

For each sample, Figs. 5, 6 and 7 report details of the morphological and textural modifications after experiments. We describe here the main features taking into account the experimental conditions ( $\mathrm{T}$ and OQT versus SQT).

PZ COLOR

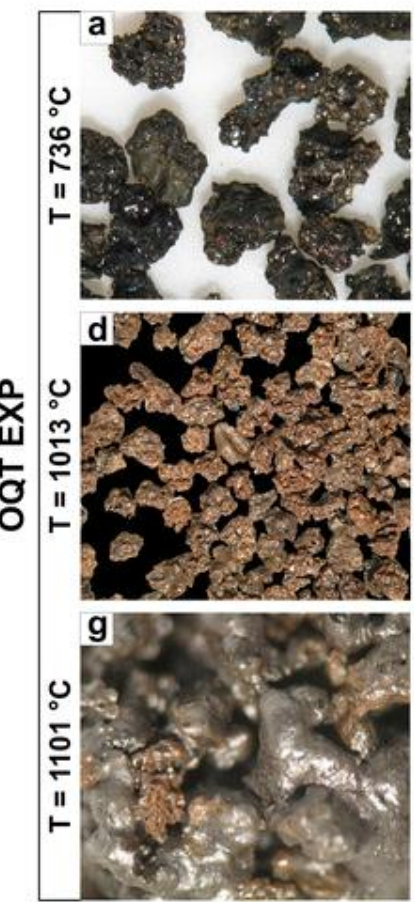

EXTERNAL MORPHOLOGY
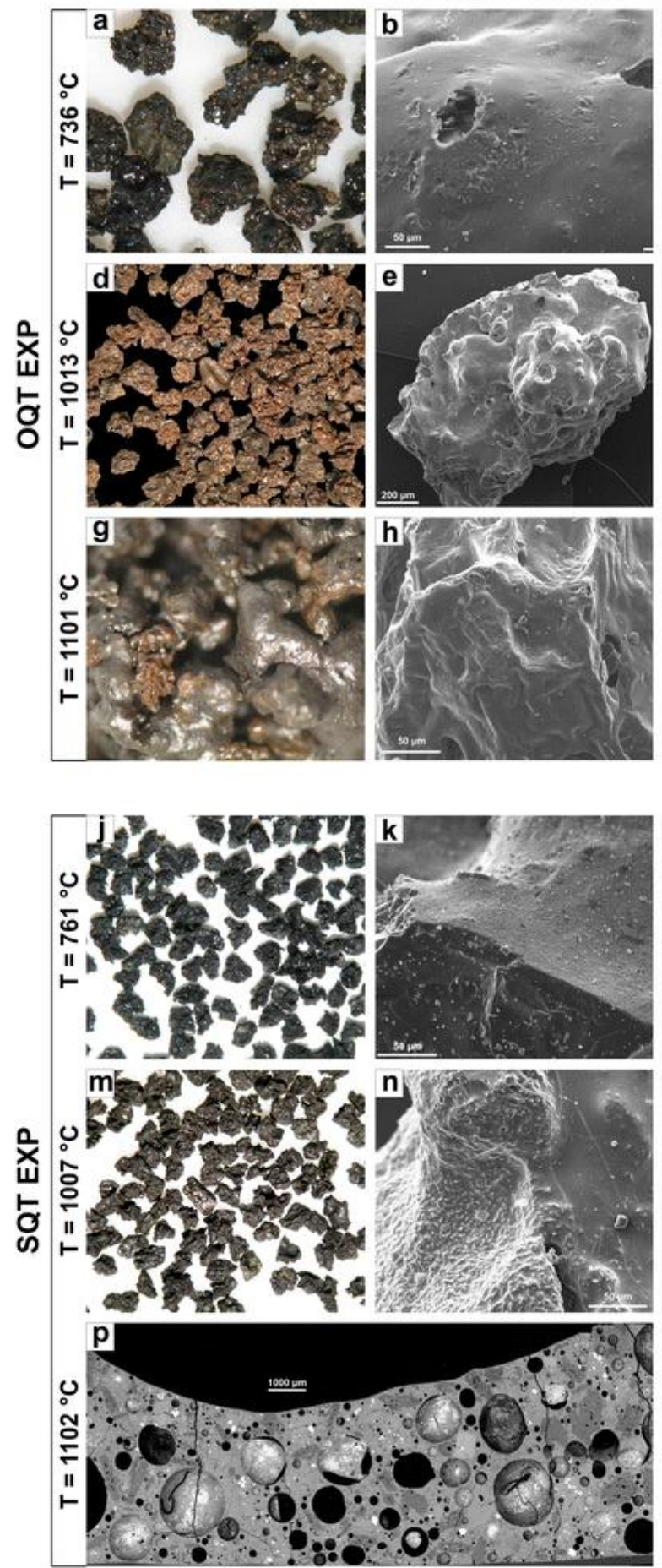

\section{GROUNDMASS RUn-DESCRIPTION} TEXTURE
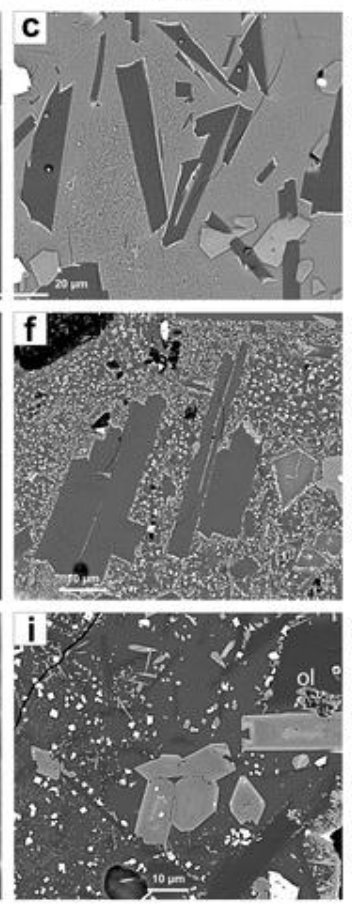

\#PZ10 - Upper part of the capsule (exposed to the air): inhomogeneous clast reddening. Clast deformation, sintering, primary vesicularity erased, growth of new minerals on the surfaces. Partial matrix crystallization (cpx, pl, Ti-mag).

Inherited Ti-mag and ol show exsolution textures.

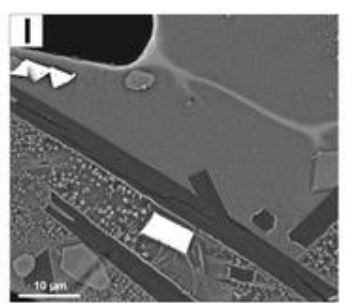

\#PZ29 - Dark and bright external surfaces, slightly smoothed for an incipient softening. Sublimates of $\mu \mathrm{m}$-sized, euhedral, equidimensional $c p x$ and magnesioferrite spinel grow on the external surface. Inhomogeneous nucleation of crystallites in groundmass.

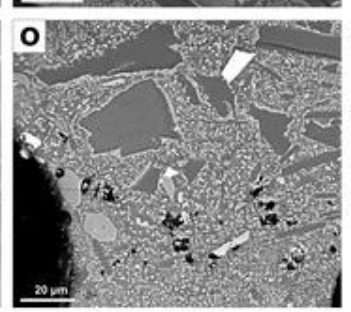

\#PZ16 - Surfaces show a metallic luster and darkening. Incipient sintering and smoothing of external surfaces. Pronounced crystallization of the groundmass with nucleation and growth of Ti-mag, $\mathrm{pl}$ and $\mathrm{cpx}$.

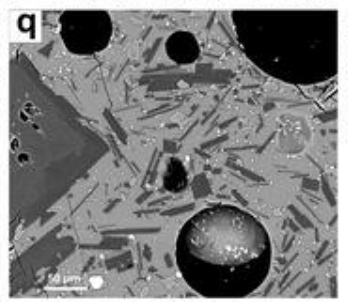

\#PZ13 - Total melting of glass, bubble nucleation and coalescence, inhomogeneous nucleation and growth of $\mathrm{pl}, \mathrm{cpx}$ and minor Ti-mag.

Fig. 5 : Color, external morphology, groundmass texture and description of the main modifications shown by Etnean samples (PZ) after reheating in different ranges of temperature and redox conditions (OQT and SQT) 


\section{STASH COLOR}


EXTERNAL MORPHOLOGY
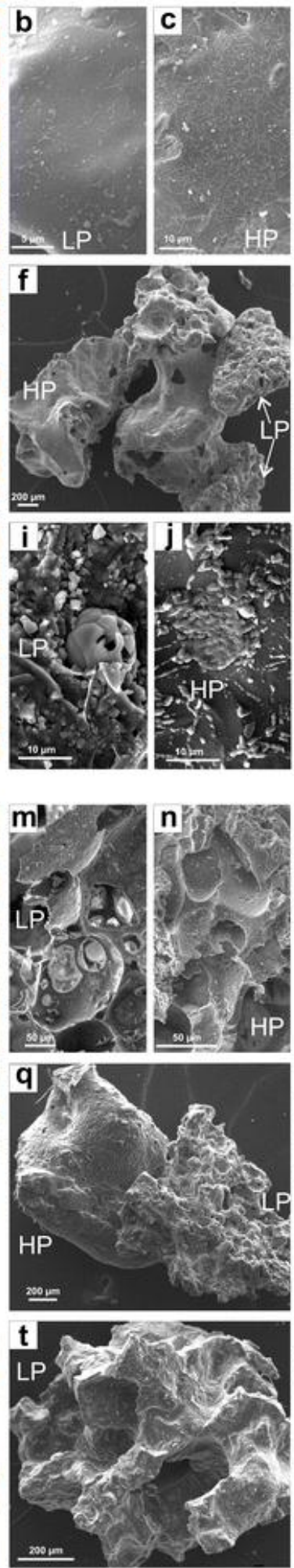

\section{GROUNDMASS Run-DESCRIPTION} TEXTURE
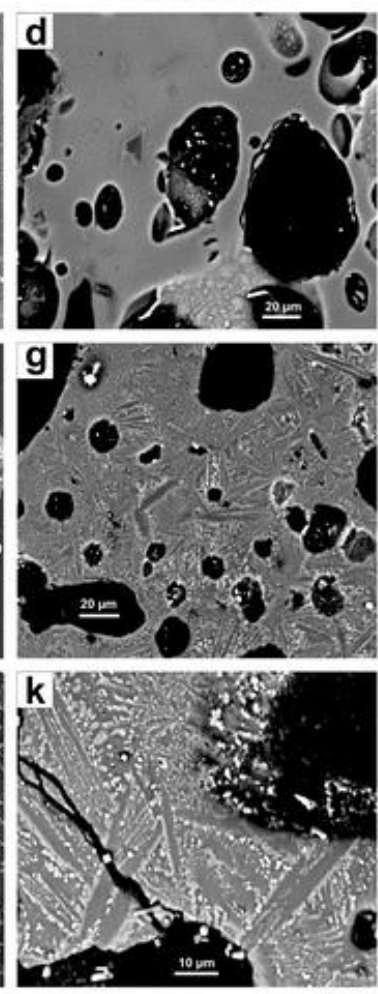

\#STASH11 - Partial reddening. Sintering and pronounced smoothing of external surfaces. Growth of micron size crystals on external surfaces. Complete groundmass crystallization (elongate swallowtail pl intergrown with granular oxide).

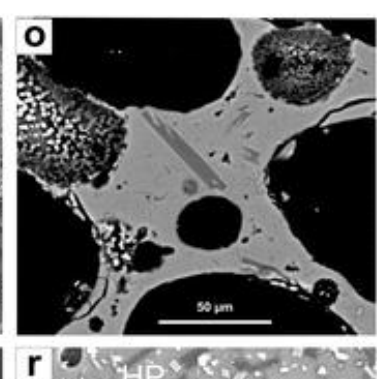

\#STASH3 - Partial darkening and dulling of clast surfaces, no modification of external morphology, abundant sublimates on the clast surfaces. No microlite n u c l e a t i o n a n d modification/nucleation of bubbles.

$\mathbf{u} \quad \mathbf{v}$ \#STASH - HP - Sample HP : $\quad$ a $\quad$ New spherical bubbles ( a few to (1) hundreds $\mu \mathrm{m}$ in diameter). The 1 . 5 . 1. 3 a


surfaces. Partial groundmass crystallization (spherulitic intergrowth of $\mathrm{pl}$ and $\mathrm{cpx}$ ).

Fig. 6

Color, external morphology, groundmass texture and description of the main modifications shown by Stromboli (STASH) samples after reheating in different ranges of temperature and redox conditions (OQT and SQT) 
VES

COLOR


p
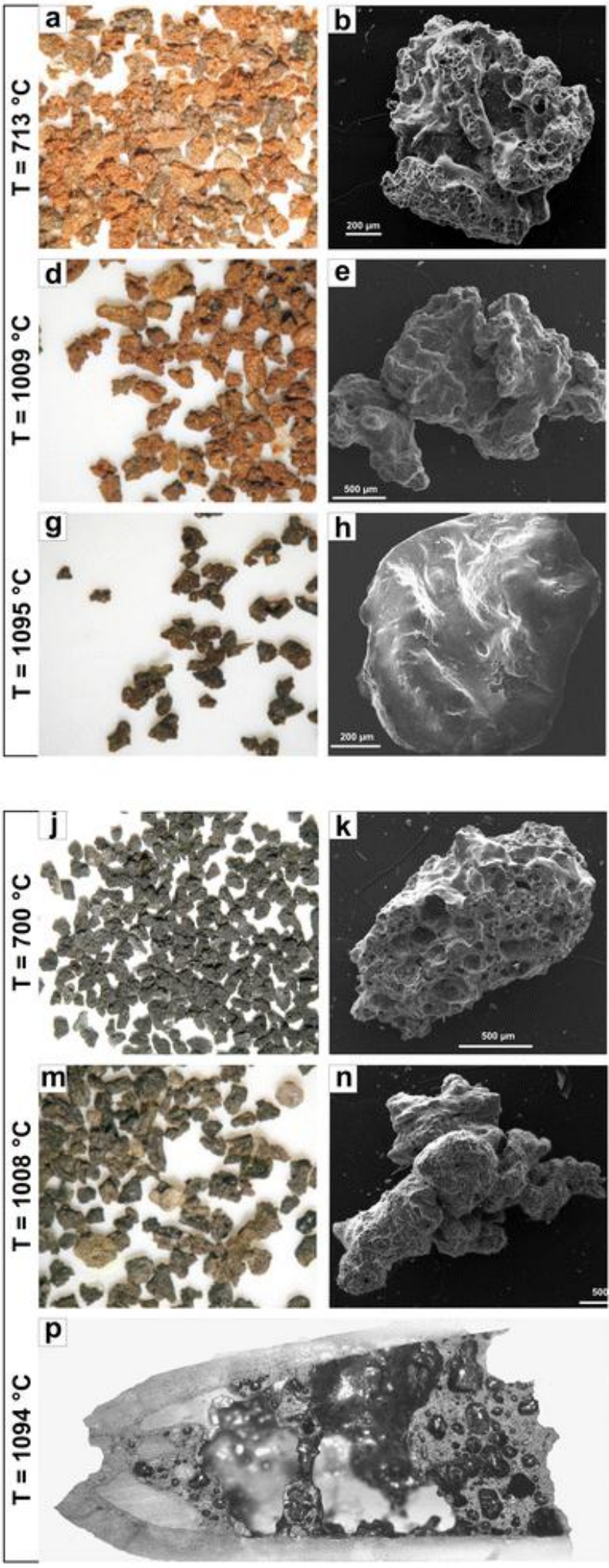

GROUNDMASS RUn-DESCRIPTION TEXTURE

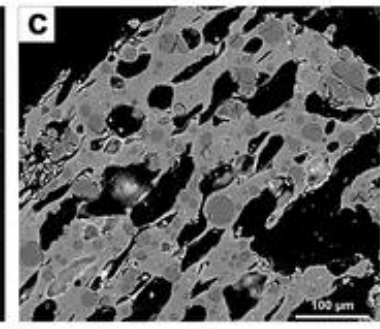

EES1- Reddening no modification of external

morphology, incipient microlite nucleation, no modification / nucleation of bubbles
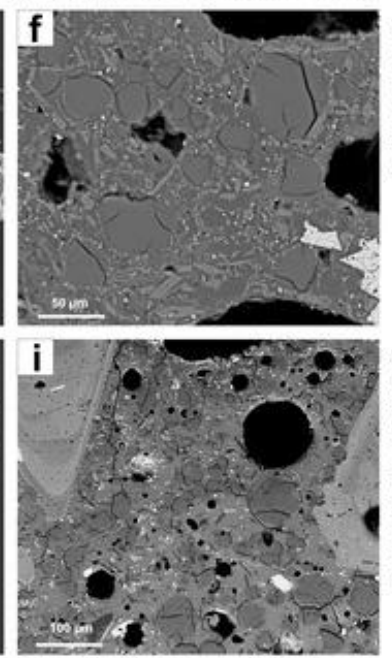

\#VES11 - Upper part of the capsule (clasts exposed to the air): reddening of clasts and matrix crystallization (mainly $\mathrm{Ti}$ mag); middle/lower part of the capsule: glass melting, bubble nucleation and coalescence, inhomogeneous microlite crystallization.

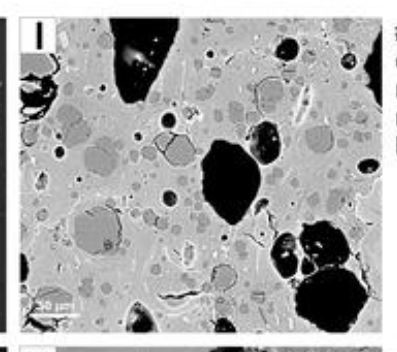

\#VES3 - Dulling and graying of clast surfaces, incipient microlite nucleation, no modification/nucleation of bubbles
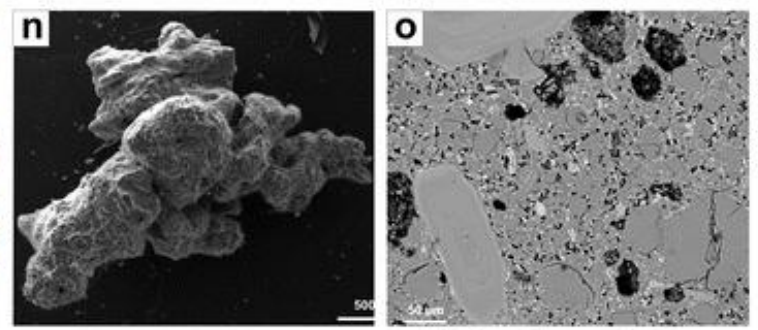

\#VES8 - Darkening and dulling of surfaces. Sintering, matrix crystallization (mainly $\mathrm{cpx}$ ), collapse of pre-existing bubbles and nucleation of $\mu$-sized bubbles on external surfaces.

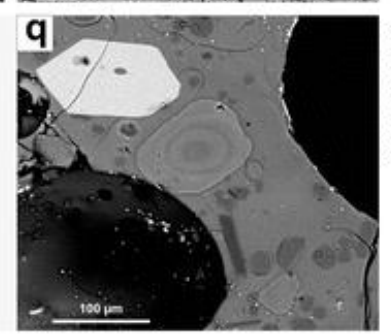

\#VES10 - Total melting of glass, bubble nucleation and coalescence, inhomogeneous microlites nucleation and growth.

Fig. 7

Color, external morphology, groundmass texture and description of the main modifications shown by samples from Vesuvius (VES) after reheating in different ranges of temperature and redox conditions (OQT and SQT) 
We use hereafter the term devitrification with the same meaning as in the glass and ceramic literature to indicate nucleation and growth of crystallites following glass reheating.

OQT experiments

$700-750^{\circ} \mathrm{C}$ : Reheating at low temperature induces a modification of the external surface of the clast, confined in few microns of thickness. All clasts change in color, which turn toward tones of orange-red (Figs 5a, 6a, 7a). In particular, in the run \#PZ15 fragments show an overall metallic luster of the external surface, with reddening confined to the bubbles walls (Fig. 5a).

In the charge \#STASH1, the HP and LP portions take on different shades of orange-red, with the former turning more to brown than the latter (Fig. 6a). Modification of the external surface of the clasts is related to the formation of a network made of lath-shaped (less than $5 \mu \mathrm{m}$ in length, probably $\mathrm{pl}$ and oxides) and globular crystallites (less than $1 \mu \mathrm{m}$ in size, possibly cpx) (Fig. 6b, c). In the groundmass, the nucleation of crystallites is associated with the growth of swallowtail microlites of pl (Fig. 6d). The abundance of newly formed microlites is clearly higher in HP than in LP groundmasses.

In charge \#PZ15, the overall shape of the clasts appears slightly smoothed, as well as the external glass starts to soften (wrinkled or smoothed surface) and new bubbles grow on the surfaces (Fig. 5b). Tiny fractures propagate on the external surface of the clasts, not associated with microlite crystallization. Matrix glass shows evidence of devitrification, as suggested by the inhomogeneous distribution of crystallites within the groundmass (Fig. 5c). In addition, pre-existing microlites of plagioclase act as sites for the heterogeneous nucleation of bladed and fan-shaped plumose spherulites, interpenetrating plagioclase microlites. Oxides form anhedral, dendritic microlites. Pre-existing crystals of Ti-mag show typical "trellis" texture, consisting in lamellae of ilmenite in magnetite (Haggerty 1991). In charge \#VES1, modifications of external morphology of the clasts are not visible (Fig. 7b), while groundmass glass shows evidence of incipient devitrification (Fig. 7c).

$1,000-1,050^{\circ} \mathrm{C}$ : The color of all the ash clasts changes, turning red-brown (Figs. 5d, 6e, 7d). External surfaces are smoothed as a consequence of the glass softening (Figs. 5e, 6f, 7e). The extent of sintering depends on the duration of the experiments: in short runs $(<40 \mathrm{~min}$, for example, \#PZ1) clasts do not adhere to each other, while in longer experiments, the sintering increases inducing a moderate welding for \#PZ1 and \#VES2. This process corresponds to the clast densification and pore reduction described by Grunder and Russell (2005). In \#STASH2, the LP portion shows incipient sintering at $1,000{ }^{\circ} \mathrm{C}$ and moderate sintering at $1,050{ }^{\circ} \mathrm{C}$. Conversely, HP portions are moderately sintered already at $1,000{ }^{\circ} \mathrm{C}$. In all samples, preexisting bubbles collapse and new micrometer-sized vesicles grow on the external surfaces. A similar feature has also been observed in heating experiments of Kennedy et al. (2010) (regime 2 and 3) though their charges refer to a rhyolitic composition. New microlites (likely cpx, oxides and pl) precipitate and grow on the external surface of clasts as vapor-phase products, generally forming clusters around bubbles and fractures. Small grains of oxides form within the glass on the internal rim of clasts and on bubble walls. Tiny fractures are visible on the external surfaces. 
In all samples, the groundmass is nearly totally crystallized, with a predominant nucleation and growth of oxides, mainly along the rim of pre-existing plagioclase (Fig. 5f), leucite together with euhedral/swallowtail cpx (Fig. 7f) or intergrown with either feathery dendritic pyroxene (Fig. 6g) or elongate swallowtail plagioclase (Fig. 5f). In all samples, crystals of Timag show "trellis" texture.

1,090-1,100 ${ }^{\circ} \mathrm{C}$ : All the experiments carried out at these conditions produce material with contrasting features, depending on the position within the quartz tube and sample composition (Fig. 8). In all samples, the topmost part of the charge, directly exposed to the air (about $1 \mathrm{~cm}$ thick), develops a red-yellow color (Figs. 5g, 6h, 7g). Here, new bubbles nucleate and coalesce on the external surface of the clasts, which appears "frothy." The thickness of this upper portion remains constant irrespective of the duration of the experiments. SEM inspection indicates that the external surfaces of the clasts are smoothed and pre-existing vesicles results to be completely collapsed (Figs. $5 \mathrm{~h}, 7 \mathrm{~h}$ ). Clasts sintering is highly variable within this portion, ranging between absent and moderate. Modification of groundmass vesicularity is also largely variable, with quite unaltered clasts occurring together with clasts carrying large, ameboid-shaped, collapsed bubbles. In all the samples, however, new, micrometer-sized, rounded bubbles nucleate (Fig. 7i). Fe-Ti oxides, cpx and pl form in the groundmass. Two oxides population can be distinguished on the basis of their habits and size. We observe: (1) a very fine-grained population of crystallites, growing along the external clast rim and, forming $1-\mu \mathrm{m}$ thick, almost continuous film and (2) a small $(<50 \mu \mathrm{m})$, dendritic, hopper population, variably distributed in the groundmass (Figs. 5i, 6i, j, k, 7i). Similarly, we observe cpx microlites that nucleate and grow within the groundmass, and a significant quantity of cpx microlites that nucleate heterogeneously on pre-existing phenocrysts and on the internal rims of the clasts. Plagioclase is mostly euhedral and nucleates and grows as acicular laths. 

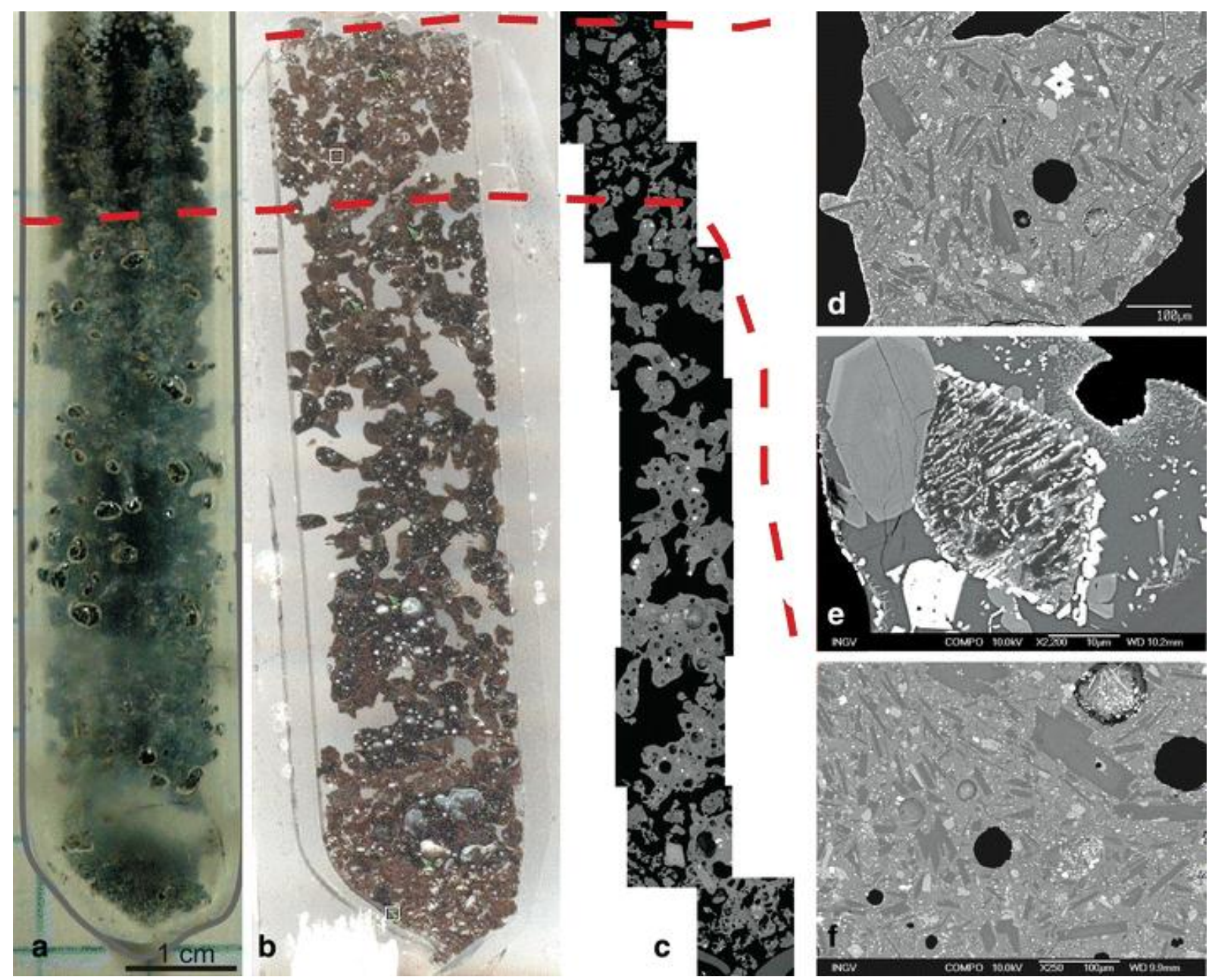

Fig. 8 : Example of OQT charge at high temperature (\#PZ10) showing the sharp textural variations within the experimental cell from top to bottom; a whole capsule; b epoxy embedded thick section of the capsule; c mosaic of BSE-SEM images of the whole capsule; $d$ BSE-SEM close-up image of the topmost part of the capsule; e BSE-SEM image of an olivine phenocryst substituted by the graphic intergrowth of magnetite and forsterite; $\mathrm{f} \mathrm{BSE-}$ SEM close-up image of the middle part of the capsule

The middle/lower part of the capsule is characterized by a complete sintering and welding of the clasts (Fig. 8a, b). Boundaries of single clasts are no more recognizable and this portion of the charge forms a single mass, containing crystals and large vesicles (Fig. 8b, c) deriving from migration and coalescence of intraclasts air. In this portion of the capsule (Fig. $\underline{8}$ ), the groundmass is less crystallized relative to clasts directly exposed to the air, and features a random distribution of microlites (Fig. 8d). Microlites include cpx, pl (plus lct in \#VES11) and minor oxide. Microlites nucleate and grow both from pre-existing glass and (mainly cpx and oxides) on the internal surface of the clast as well as along the contact with pre-existing minerals. Inherited microphenocrysts of Ti-mag show typical "trellis" texture, while olivine phenocrysts are substituted by the graphic intergrowth of magnetite and forsterite (Fig. $\underline{\text { ee) }}$ (Haggerty and Baker 1967). Small glassy, microlite-free zone are present. 
SQT experiments

700-750 ${ }^{\circ}$ : The color of the clasts remains quite unaltered in run \#PZ29 (Fig. 5j), the external surfaces being still bright and dark, while in charges \#STASH3 and \#VES3, the external surfaces are dull and darkened (Figs. 61, 7j). Angularity of external surfaces decreases due to an incipient softening, and the overall shape of the clasts and the external vesicularity are unmodified (Figs. 5k, 6m, n, 7k). In all samples, sublimates of micrometersized, euhedral, equidimensional cpx and magnesioferrite (Mfr) spinel grow on the external surface of the clasts and in particular on the bubble walls. Experiment \#VES3 results in precipitation of apatite on the external surfaces. In addition, surfaces of \#STASH3 and \#PZ29 are characterized by the occurrence of micrometer-sized euhedral crystals of $\mathrm{Cu}-\mathrm{Fe}$ sulfides (Raghavan 2006).

Groundmass is incipiently devitrified (Figs. 51, 71). In \#VES3, the concentrically arranged contraction fractures which border the leucite crystals are sealed by a very fine population of possibly cpx crystallites. LP and HP portions of \#STASH3 share the same microlite assemblage although with different abundances. As a general rule, HP glasses have lower crystal content with respect to LP ones. Crystal-free zones of glass are abundant, and the modification seems to be confined to the periphery of the clasts.

$1,000-1,050^{\circ} \mathrm{C}$ : The ash color turns gray-brown and dull (Figs. $5 \mathrm{~m}, 6 \mathrm{p}, 7 \mathrm{~m}$ ). Some clasts show a weak sintering (Figs. 6q, 7n). Generally, the extent of sintering increases with temperature. Surfaces of the clasts are smoothed, and a reduction in size and abundance of bubbles occurs. The pre-existing vesicularity is completely obliterated in runs \#PZ2, \#VES8 and \#STASH9 (HP portion), while in \#STASH9 (LP; Fig. 6q), the rims of original bubbles become irregular as a consequence of bubble collapse and groundmass crystallization. New, rounded, micrometer-sized bubbles grow in the groundmass. All the samples are characterized by a holocrystalline groundmass made by micron-sized cpx, oxides, ol and pl in different proportions (Figs. 5o, 7o). Very small microlite-free portions of glass are heterogeneously distributed within each single clast. In charge \#STASH9 (Fig. 6r), HP zones preserve large areas of glass with euhedral microlites, while LP zones are nearly holocrystalline, with spherulitic intergrowths of $\mathrm{pl}$ and cpx.

1,090-1,130 ${ }^{\circ}$ : Runs \#PZ13, \#STASH8 and \#VES10 (Table $\underline{3}$ ) result in the welding of the sample (Figs. 5p, 6s, 7p). The original boundaries of clasts are completely obliterated and the sample appears as a single glassy mass embedding crystals. Intergrain air, trapped in the glass during the compaction and welding, forms spherical bubbles ranging in diameter from a few to hundreds of microns. The pre-existing crystals (pl in \#PZ13 and \#STASH8, cpx and lct in \#VES10) are partially resorbed. New, abundant microlites grow in the groundmass (Figs. 5q, 6u, 7q). In \#STASH8, pl shows a newly formed micron-thick rim, with a composition similar to that of $\mathrm{pl} \mathrm{microlites} \mathrm{grown} \mathrm{in} \mathrm{the} \mathrm{groundmass} \mathrm{(Fig.} 6 \mathrm{u}$ ). Subordinate interstitial glass is still present.

Differently from the above described runs, \#STASH7 only results in a moderate softening and sintering of the clasts. External surfaces of clasts are smooth and rounded, and the preexisting vesicularity is completely resorbed (Fig. 6t). Abundant spherulites of cpx, pl and 
subordinate ol and oxides grow in the groundmass. Interstitial glass between spherulites of $\mathrm{pl}$ and cpx is present. Groundmass is partially glassy and contains spherulites of $\mathrm{pl}$ and cpx. Phenocrysts of ol inherited from HP magma show exsolution texture.

\section{Compositional features}

Groundmass glass was analyzed in all starting materials and run products obtained under SQT conditions. These samples are suitable for EPM analysis, because large glass patches are preserved in the groundmass (Table 3). Conversely, OQT experimental charges are more difficult to analyze since the groundmass is crystal-rich and glass is only locally preserved. In the latter case, the only available glass compositions correspond to experiments performed at 700-750 and $1,090-1,120^{\circ} \mathrm{C}$. Contamination of the clasts by the quartz tube is limited and concentrated to a few-micron-wide belt close to the contact with the capsule.

$\mathrm{CaO} / \mathrm{Al}_{2} \mathrm{O}_{3}$ versus $\mathrm{SiO}_{2}$ /alkali, $\mathrm{FeO} / \mathrm{MgO}$ and $\mathrm{K}_{2} \mathrm{O} / \mathrm{TiO}_{2}$ variations within glasses are reported (Figs. 9, 10, 11) for the different starting compositions. These diagrams allow to recognize the compositional effects of precipitation/dissolution of mineral phases induced by experiments. 


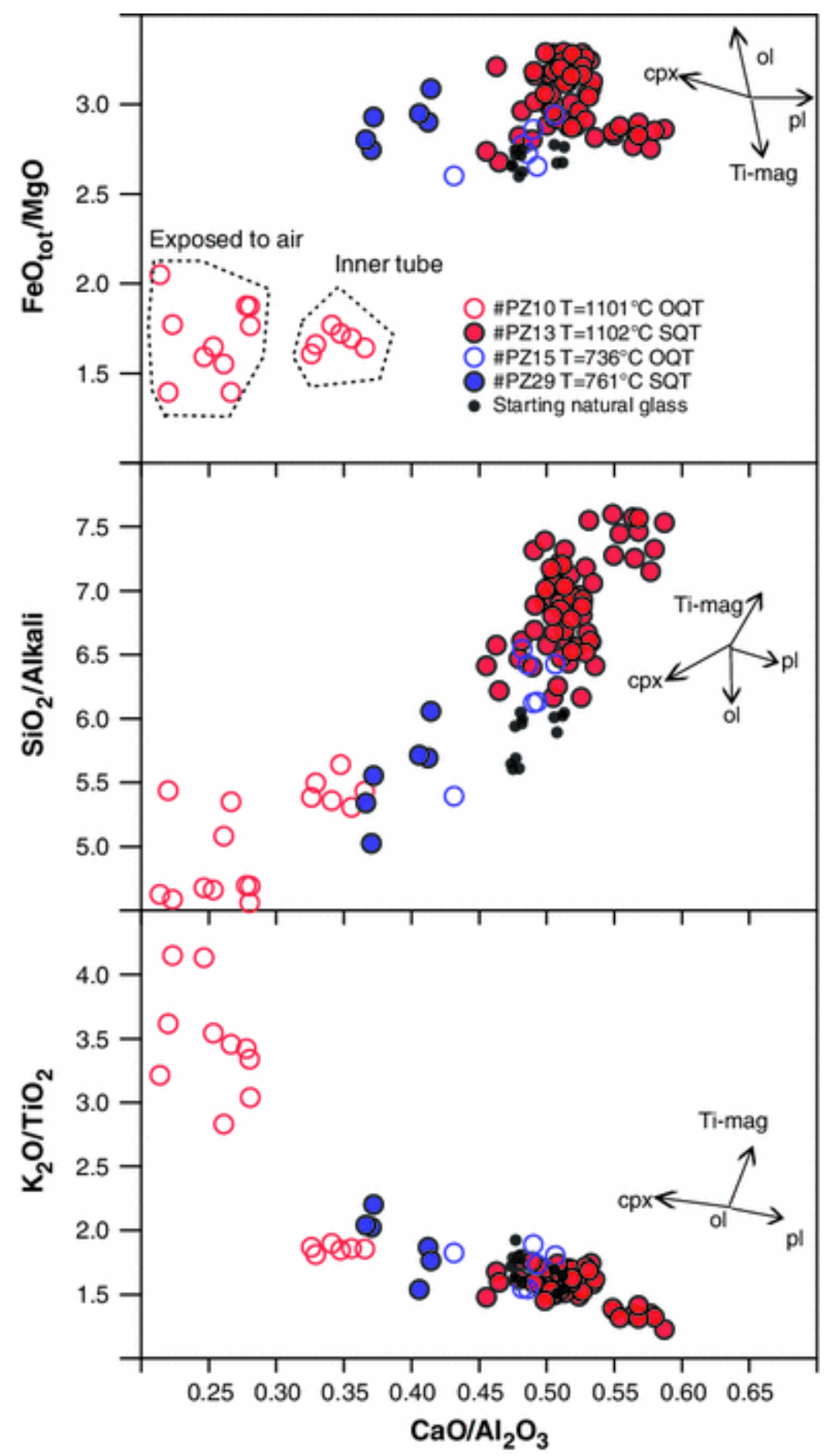

Fig. 9 : Compositional variability of matrix glasses in natural and experimental samples of Etna (PZ). The arrows show approximately the direction of shifts due to fractional crystallization of indicated mineral phases (pl plagioclase, Ti-mag Ti-magnetite, ol olivine, cpx clinopyroxene) 




Fig. 10 : Compositional variability of matrix glasses in natural and experimental samples of Stromboli (STASH). The arrows show approximately the direction of shifts due to fractional crystallization of indicated mineral phases (pl plagioclase, Ti-mag Ti-magnetite, ol olivine, cpx clinopyroxene) 


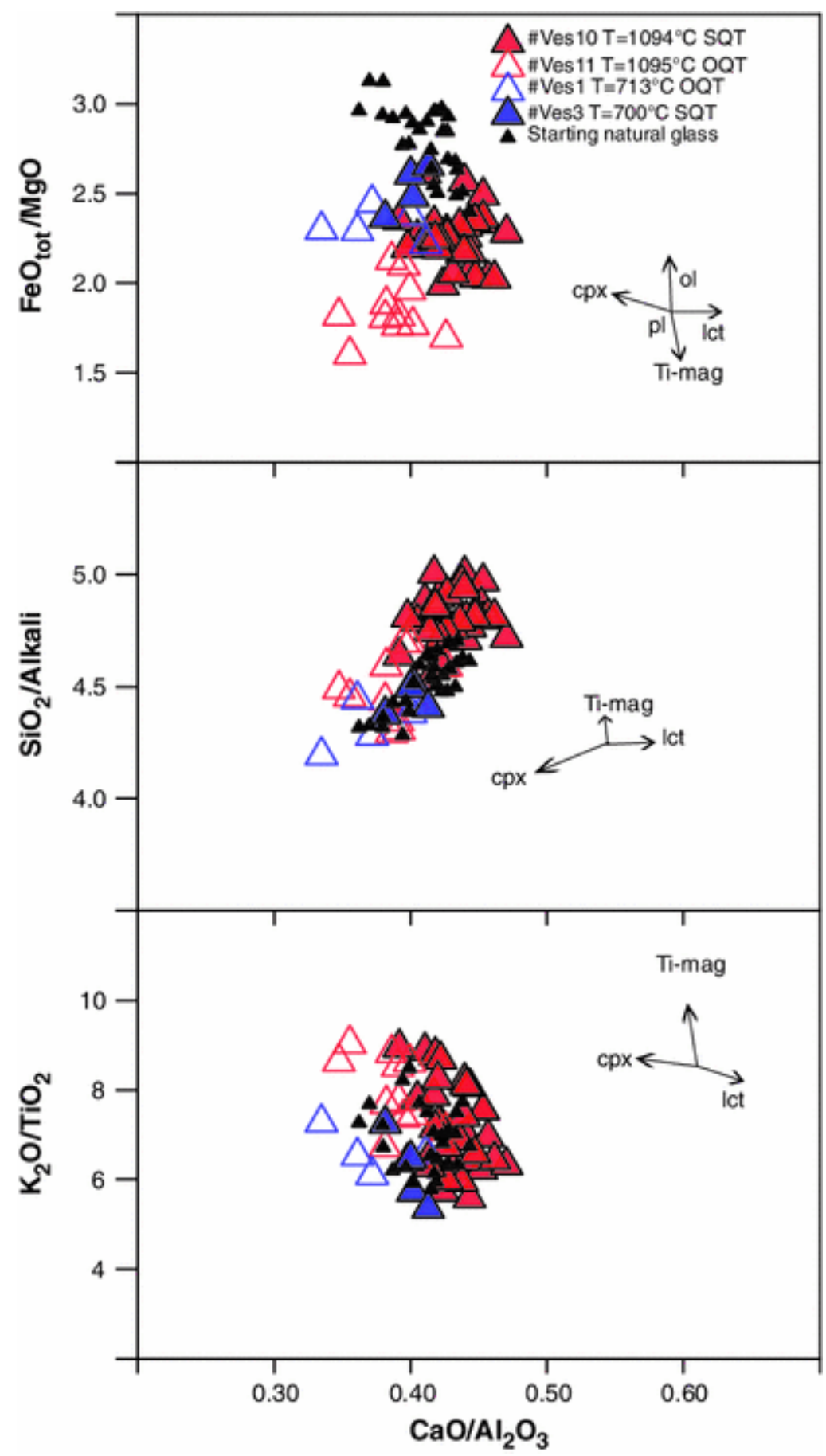

Fig. 11 : Compositional variability of matrix glasses in natural and experimental samples of Vesuvius (VES). The arrows show approximately the direction of shifts due to fractional crystallization of indicated mineral phases (pl plagioclase, Ti-mag Ti-magnetite, ol olivine, cpx clinopyroxene, lct leucite) 


\section{PZ experiments}

The starting glass is homogeneous $\left(\mathrm{CaO} / \mathrm{Al}_{2} \mathrm{O}_{3}: 0.47-0.51\right.$ and $\left.\mathrm{FeO} / \mathrm{MgO} 2.6-2.78\right)$ and comparable with glass composition reported for the products of the recent explosive activity at Etna (Corsaro and Pompilio 2004; Corsaro et al. 2007). Glass compositions measured in experimental run products reflect the type and extent of crystallization/resorption paths occurring at different experimental conditions (Fig. 9).

At low temperature, glass composition is only slightly modified, consistent with textural observations. The charge produced at low $\mathrm{fO}_{2}$ conditions (\#PZ29) shows lower $\mathrm{CaO} / \mathrm{Al}_{2} \mathrm{O}_{3}$, $\mathrm{FeO} / \mathrm{MgO}, \mathrm{K}_{2} \mathrm{O} / \mathrm{TiO}_{2}$ and $\mathrm{SiO}_{2} / \mathrm{Alk}$ ratios than natural ones, as a consequence of minor cpx crystallization.

In SQT conditions, the sample kept at $1,100{ }^{\circ} \mathrm{C}(\# \mathrm{PZ13})$, displays an overall homogeneity and partially overlaps compositions of natural glasses, extending toward slightly higher values of $\mathrm{CaO} / \mathrm{Al}_{2} \mathrm{O}_{3}, \mathrm{SiO}_{2}$ /alkali and lower $\mathrm{K}_{2} \mathrm{O} / \mathrm{TiO}_{2}$. This trend is possibly related to the crystallization of plagioclase in the groundmass during reheating. Conversely, the largest variations in glass composition is recorded by the $1,100{ }^{\circ} \mathrm{C}$, OQT runs (\#PZ10). Glass chemistry expands toward low $\mathrm{CaO} / \mathrm{Al}_{2} \mathrm{O}_{3}, \mathrm{FeO} / \mathrm{MgO}, \mathrm{SiO}_{2}$ /alkali values and high $\mathrm{K} 2 \mathrm{O} / \mathrm{TiO}_{2}$, related to an extensive Ti-mag crystallization. The vertical gradient of the clast texture observed along the capsule (Fig. $\underline{8} \mathrm{a}, \mathrm{b}$ and c) is evident also in glass chemistry. In particular, clasts exposed to the air are characterized by the lowest $\mathrm{CaO} / \mathrm{Al}_{2} \mathrm{O}_{3}, \mathrm{FeO} / \mathrm{MgO}, \mathrm{K} 2 \mathrm{O} / \mathrm{TiO}_{2}$ and $\mathrm{SiO}_{2} /$ alkali, accounting for a significant precipitation of cpx, $\mathrm{pl}$ and Ti-mag. Clasts in the middle part of the quartz tube are characterized by a glass composition intermediate between the starting material and that of clasts exposed to the air, suggesting that they only underwent a limited crystallization of the same phases.

\section{STASH experiments}

Glass in LP starting material is homogeneous, showing a small range of $\mathrm{K}_{2} \mathrm{O} / \mathrm{TiO}_{2}$ (1.4-2.5), $\mathrm{FeO} / \mathrm{MgO}$ (1.2-1.5) and $\mathrm{SiO}_{2}$ /alkali ratios (10-11.3). Glass in HP starting material has higher $\mathrm{FeO} / \mathrm{MgO}$, lower $\mathrm{CaO} / \mathrm{Al}_{2} \mathrm{O}_{3}$ and $\mathrm{SiO}_{2} /$ alkali than LP glass, but comparable $\mathrm{K}_{2} \mathrm{O} / \mathrm{TiO}_{2}$ (Fig. 10).

Glass composition for low-T runs $\left(\mathrm{T}=700-750{ }^{\circ} \mathrm{C}\right)$ is comparable with that measured on LP natural shards. However, in OQT experiments (\#STASH1), glass composition is more scattered and some analyzed spots are recognizable for low $\mathrm{Na}_{2} \mathrm{O}$ content, following a minor effect of $\mathrm{Na}_{2} \mathrm{O}$ diffusion (see also Hammer 2006). Other clasts, instead, show low $\mathrm{CaO} / \mathrm{Al}_{2} \mathrm{O}_{3}$ ratio, due to local crystallization of $\mathrm{pl}$ and cpx. After reheating under SQT condition (\#STASH3), glasses have slightly higher $\mathrm{MgO}, \mathrm{SiO}_{2}, \mathrm{FeO}$ and $\mathrm{Na}_{2} \mathrm{O}$ and lower $\mathrm{K}_{2} \mathrm{O}$ than starting material, as a consequence of local diffusion of these elements during the devitrification process.

Between 1,000 and $1,050^{\circ} \mathrm{C}$ (\#STASH4), glass compositions show significant variability. Experiments at $1,050{ }^{\circ} \mathrm{C}$ produce glass that partially overlaps those performed at $1,120^{\circ} \mathrm{C}$ (\#STASH7), as a consequence of significant pl crystallization. At $1,000{ }^{\circ} \mathrm{C}$ (\#STASH9), the high crystal content of the groundmass precludes any analysis. However, the few analyzed 
glass pools show a large compositional range on the diagram $\mathrm{CaO} / \mathrm{Al}_{2} \mathrm{O}_{3}$ versus $\mathrm{FeO} / \mathrm{MgO}$, extending from the natural glass composition toward HP magma compositions. This trend is consistent with crystallization of cpx, and minor amount of $\mathrm{pl}$ and $\mathrm{ol}$.

At high temperature $\left(>1,100{ }^{\circ} \mathrm{C}\right)$, groundmass obtained in OQT runs is totally crystallized. On the other hand at comparable T but under SQT conditions (\#STASH7-8), the glasses are strongly heterogeneous in composition. They span toward the lowest $\mathrm{CaO} / \mathrm{Al}_{2} \mathrm{O}_{3}$ and $\mathrm{SiO}_{2}$ /alkali ratios and attain the highest $\mathrm{K}_{2} \mathrm{O} / \mathrm{TiO}_{2}$ values of the whole dataset. $\mathrm{FeO} / \mathrm{MgO}$ ratio does not change with respect to that of the starting material. This is compatible with a crystallization of prevalent $\mathrm{pl}$, starting from an LP natural glass. In the same experimental conditions, the only experiment carried out on pure HP scoria at $1,113{ }^{\circ} \mathrm{C}$ (\#STASH8) results in a glass which is compositionally indistinguishable from the HP starting material, indicating a lack of significant crystallization after reheating.

\section{VES experiments}

The starting glasses have highly variable composition (Fig. 11), typical of the products of ashdominated eruptions at Vesuvius (Cioni et al. 2008; D’Oriano et al. 2011).

Glass in experiments carried out at low temperature $\left(\approx 700^{\circ} \mathrm{C}\right)$ differs from the natural ones only for the lower $\mathrm{FeO} / \mathrm{MgO}$ ratio. This feature is more evident for experiments carried out under OQT conditions (\#VES1) and it is mainly related to Ti-mag and cpx crystallization.

At high temperature $\left(\approx 1,090{ }^{\circ} \mathrm{C}\right)$ and under SQT conditions (\#VES10), glass composition almost overlaps the composition of the natural glassy fragments, although experimental glasses show a $\mathrm{FeO} / \mathrm{MgO}$ ratio slightly lower than the starting material, possibly related to the crystallization of Ti-mag. $\mathrm{CaO} / \mathrm{Al}_{2} \mathrm{O}_{3}$ and $\mathrm{SiO}_{2}$ /alkali ratios instead shift toward slightly higher values, likely associated with minor dissolution of plagioclase crystals.

At the same temperature but under OQT conditions (\#VES11), fragments from the topmost part of the capsule have a completely crystallized groundmass, in which the glass cannot be analyzed. In Fig. 11, we report glass compositions analyzed in fragments of the middle and lower parts of this charge. Measured ratios are quite similar to those of natural glasses even if they shift toward slightly lower $\mathrm{FeO} / \mathrm{MgO}$ and higher $\mathrm{K}_{2} \mathrm{O} / \mathrm{TiO}_{2}$ values. This indicates that the central portion of the capsule experienced only a slight crystallization of oxides and minor cpx.

\section{Discussion}

The experimental data show that the most important physical and chemical effects resulting from reheating of natural pyroclasts at different temperatures and redox conditions are: (1) groundmass crystallization and subsequent compositional changes of matrix glass; (2) softening, sintering and welding of clasts; (3) vapor-phase mineral precipitation on external surfaces; (4) surface color change; (5) subsolidus transformation of some mineral phases (e.g., development of symplectic texture in olivine or oxide exsolution). 


\section{Groundmass crystallization and change of glass composition}

In principle, the mineral assemblages, crystal contents and glass compositions of natural material are assumed to represent the state of the magmatic melt as quenched immediately after fragmentation. It is usually assumed that quenching after fragmentation is highly efficient and capable of interrupting reaction kinetics. This is thought to be especially true in the case of the fine-grained fragments considered in our experiments. Thus, erupted products can reflect the pre-eruptive equilibrium conditions attained by the magma or, most probably, they represent a metastable state which records the conditions reached by magma following syn-eruptive decompression-related degassing. In this case and because of degassing, a large undercooling (i.e., difference between liquidus temperature and the temperature of the magma) is recorded in the quenched system. Experimental reheating reactivates the melt allowing for new chemical and physical processes that will move the melt closer to equilibrium. In our case, the new conditions imposed by experiments can be either very close to $\left(\mathrm{T}=1,000-1,100{ }^{\circ} \mathrm{C}, \mathrm{SQT}\right)$ or very far from $\left(\mathrm{T} \approx \mathrm{T}_{\mathrm{g}}\right.$; OQT) the syn-eruptive thermal and redox conditions. After reheating, transport parameters such as chemical and thermal diffusion will control the response of the sample. Although we can neglect the effects of thermal diffusion (the whole charge attains thermal equilibrium in few minutes due to geometry of the experiments and size of the capsule), compositional diffusion is a more complex parameter strongly controlled by melt viscosity which is itself controlled by temperature, melt polymerization and composition.

Redox conditions control liquidus temperature $\left(\mathrm{T}_{\text {liq }}\right)$, mineral assemblage (e.g., oxide crystallization) and then the liquid line of descent (LLD) of a magma (e.g., Hamilton et al. 1964). For example, thermodynamic modeling (by MELTS code of Asimow and Ghiorso 1998; Ghiorso and Carmichael 1985) reveals an increase in the liquidus temperature (i.e., for Etna basalt) of $30-40{ }^{\circ} \mathrm{C}$ as the oxygen fugacity changes from QFM to that of the air. The lower is the $\mathrm{Fe}^{2+} / \mathrm{Fe}^{3+}$ ratio, the higher the $\mathrm{T}_{\text {liq }}$ of a silicate melt. This is because ferric iron $\left(\mathrm{Fe}^{3+}\right)$, generally occurring in tetrahedral coordination, acts as a network former (Mysen 1983; Dingwell and Virgo 1987), inducing a general increase in melt polymerization and promoting crystallization. In addition, an increasing proportion of $\mathrm{Fe}^{3+}$ favors the precipitation of a larger amount of oxides, so changing the ratio between mafic and salic minerals (Bouhifd et al. 2004) and the composition of the residual melt.

In our experiments, different redox conditions induce major changes in groundmass crystallization and glass composition (Figs. 5,6,7,8,9,10,11; Table 3). These effects are more or less significant depending on the operating temperature. In all the experiments performed at temperatures close to $\mathrm{T}_{\mathrm{g}}$, groundmass crystallization is limited to the formation of a large number of crystal nuclei (crystallites or spherulites), suggesting an overall condition of high undercooling. This process creates textural heterogeneities at the scale of few microns, only partially recorded by changes in glass composition. Generally, the glass compositions remain clustered around that of the natural glasses. Minor differences are in some cases present, mainly related to local heterogeneities induced by diffusion of elements around spherulites. In this temperature range, glass resulting from heating experiments under highly oxidizing 
conditions is in general slightly more differentiated (Figs. 9,10,11) with respect to the natural glass.

In the $\mathrm{T}$ range $1,000-1,050{ }^{\circ} \mathrm{C}$, the groundmass is almost completely crystallized for all charges, except for STASH samples. New nucleated microlites or rim overgrowths on early formed microphenocrysts generally show acicular or dendritic shapes, indicating intermediate undercooling conditions (Lofgren 1974). In all charges, changes in $\mathrm{fO}_{2}$ control the mineral assemblage; crystallization of oxides over pyroxenes and feldspar/leucite are favored by high $\mathrm{fO}_{2}$ conditions (OQT).

STASH experiments, at low redox conditions (SQT), produced different textures in HP and LP samples. HP zones show euhedral microlites (low undercooling), while LP zones exhibit spherulites of $\mathrm{pl}$ and cpx, suggesting high undercooling conditions. We argue that the evident disequilibrium conditions shown by LP clasts is inherited from the syn-eruptive fast ascent and degassing conditions recorded by this magma type during Stromboli paroxysms (Métrich et al. 2010).

Close to the eruptive temperature $\left(1,100-1,130{ }^{\circ} \mathrm{C}\right)$, redox conditions are crucial in controlling the crystal content of the groundmass. In all runs produced at SQT conditions, crystallinity and glass compositions for VES, PZ and STASH-HP samples match those observed in the respective starting material. This indirectly confirms that our experiments accurately reproduce the physicochemical conditions at quenching, and that the magmatic system was nearly relaxed. On the contrary, STASH-LP clasts undergo a nearly complete crystallization, resulting in highly differentiated glasses along a trend controlled by $\mathrm{pl}$ and cpx crystallization and possibly reflecting a highly unrelaxed (disequilibrium) state of the starting material.

Under OQT conditions and the same high-T range, all charges are characterized by a largely crystallized groundmass, with Ti-mag as the predominant phase. The extent of crystallization within each clast strongly depends on the distance from the outermost portion of the clast, at the contact with the air (see also Burkhard 2001). Glass compositions (where analyzed) record oxide precipitation (lowering $\mathrm{FeO} / \mathrm{MgO}$ ratio and increasing $\mathrm{K}_{2} \mathrm{O} / \mathrm{TiO}_{2}$ ). A compositional zoning is evident in $\mathrm{PZ}$ sample, where glass from clasts exposed to the air has the lower $\mathrm{FeO} / \mathrm{MgO}$ ratio. This indicates that redox conditions were not the same over the whole capsule, and the external portion acted as a barrier/buffer to the exchange with atmospheric oxygen. The thickness of this buffering layer is not related to the duration of the heating experiment, suggesting that this interface is not controlled by diffusion but only by physical parameters, such as the permeability of the material at sample-atmosphere interface and the geometry of the capsule. According to this, we can infer that deposition of clastic material on top of a hot zone, whether in intracrater area or on the surface of an active lava flow, will show important oxidation and crystallization only in the very superficial layers.

\section{Clasts softening-sintering-welding}

At a given pressure, the processes of sintering and welding depend on composition, water concentration and temperature of the glass, inasmuch as these govern viscosity (Giordano et al. 2008; Grunder and Russell 2005 and references therein). Natural glasses in our samples 
display similar chemical compositions and can be considered almost anhydrous. This suggests that the temperature range at which the most important rheological modifications are expected to occur will be similar for all samples. For example, $\mathrm{T}_{\mathrm{g}}$ calculated on the basis of anhydrous compositions (Giordano et al. 2005) is broadly the same for all samples, varying by less than ten degrees for the three starting materials (Table 2). Similarly, NBO/T values for starting natural glasses are comparable (Table 2).

In our experiments, the transition from softening to sintering of the clasts appears strictly controlled by temperature. On the contrary, the transition from sintering to welding, characteristic of very high temperature, is also influenced by redox conditions.

At temperatures above $\mathrm{T}_{\mathrm{g}}\left(\mathrm{T}=700-750^{\circ} \mathrm{C}\right)$, glass starts to deform and a minor softening begins, as evidenced by micron-scale wrinkling of the external surface of the clasts.

Crystallization and compositional changes resulting from heating in this temperature range are limited. Varying the redox state does not affect significantly the rheology of the clasts since no differences in softening are detectable.

As temperature increases $\left(1,000-1,050{ }^{\circ} \mathrm{C}\right)$, sintering of glass develops (local disappearance of clast-clast contacts), together with bubble nucleation on the external surface of the clasts. This process increases with temperature up to $1,050{ }^{\circ} \mathrm{C}$. As observed for softening, sintering occurs irrespective of the redox conditions of the experiments.

In high temperature $\left(>1,090{ }^{\circ} \mathrm{C}\right)$ experiments, welding is an ubiquitous phenomenon in SQT experiments, while under OQT conditions, welding occurs only in the internal portions of the charges, not directly in contact with the air. In these charges, clasts close to the air interface appear only sintered, possibly related to the formation of sublimates and oxides on the external surface (Grunder and Russell 2005).

These rheological differences can be related again to changes in redox conditions that control melt polymerization, liquidus temperature and crystal content (Bouhifd et al. 2004; Dingwell and Virgo 1987; Mysen 1983). At high temperatures, groundmass glass compositions reveal a variable crystal content between the different runs, suggesting that bulk viscosity of the clasts was strongly controlled by the extent of crystallization. In the low temperature runs, characterized by limited groundmass crystallization, an increase in melt polymerization related to iron oxidation cannot be excluded.

It is worth noting that in this temperature range, clast collapse and welding are signaled by a significant densification of the whole charge. Pre-existing bubbles collapse and interclast voids progressively coalesce and migrate toward the exterior (Figs. 5p, 7p). This transition has important consequences on the bubble distribution within the resulting material. Dense clasts and bubble collapse can be thus produced not only by an efficient bubbles (or gas) separation during syn-eruptive degassing but also by prolonged permanence at high temperature during intracrater recycling. This fully agree with conclusions of Kennedy et al. (2010) who showed that progressive heat transfer due to the magma ascent is able to reduce significantly the open porosity and permeability of the rocks forming the conduit walls and the overlying plug. 


\section{Vapor-phase precipitation on external surfaces}

During experimental reheating of natural pyroclasts, secondary boiling related to groundmass crystallization or enhanced volatile diffusion promotes exsolution of a vapor phase and can be followed by precipitation of sublimates on clast surface (Stimac et al. 1996).

In all our experiments, micron-sized crystals with variable shape grow on the external surfaces of the clasts or form a lining on the bubble walls. The nature of these minerals is not easily recognizable, but the presence of $\mathrm{Na}, \mathrm{Ca}, \mathrm{K}, \mathrm{Al}, \mathrm{Fe}$ and $\mathrm{Si}$ suggests they are a mixture of silicate (feldspars or pyroxene) and Fe-oxide phases. In the SQT experiments, there is evidence of a sulfide phase. Abundance, shape and composition of sublimates are apparently related to temperature and to either OQT or SQT conditions. The amount of vapor-phase crystallization is also strictly related to the heating temperature, with abundant sublimates formed in experiments carried at $1,000{ }^{\circ} \mathrm{C}$.

STASH samples behave differently, showing a high content of sublimates yet at $750{ }^{\circ} \mathrm{C}$. This is in agreement with the higher volatile content of the LP portions that increases the amount of available vapor.

Experiments carried out under OQT conditions result in the formation of a more or less continuous encrustation, consisting of anhedral or subhedral crystallites. SQT conditions favor sublimates with well-developed crystal faces, possibly related to the formation of a high fluid pressure. Redox conditions which characterize SQT experiments control the composition of sublimates, favoring the crystallization of sulfide instead of Ca-sulfates (e.g., anhydrite or gypsum).

Similar crystallization of vapor phases is largely described in welded ignimbrite and occurs also in the welding experiments of Grunder and Russell (2005), especially in the presence of a high magmatic volatile content.

\section{Color change}

The color change of the external surfaces after reheating of the clasts is easily visible with the naked eye and includes both reddening and loss of luster. Both modifications occur throughout the whole range of investigated temperature, irrespective of redox conditions. This is in agreement with the experiments of reheating carried out by Tait et al. (1998), who for comparable run times documented a color change yet at $\mathrm{T}>750{ }^{\circ} \mathrm{C}$.

We also agree with the interpretation provided by Tait et al. (1998) on the different external color of the ash. It can be related to the stability of Fe-bearing phases, which depends on the oxygen fugacity conditions and temperature. In particular, at high oxygen fugacity (OQT experiments), hematite $\left(\mathrm{Fe}_{2} \mathrm{O}_{3}\right)$, typically red-yellow in color, becomes stable over the magnetite and maghemite which is present at intermediate oxygen fugacity (Mysen 1983) and low temperature.

\section{Development of exsolution textures in some mineral phases}

After reheating under OQT conditions, oxide and olivine undergo subsolidus transformations. In particular, titanomagnetite shows the typical lamellae texture (trellis texture) at $750{ }^{\circ} \mathrm{C}$. 
High temperature oxidation of basaltic olivine is a well-known process (Haggerty and Baker 1967). It results either in the exsolution of hematite associated with a more Mg-rich olivine, or in the formation of a symplectic intergrowth of magnetite and orthopyroxene. Continued oxidation of the metastable assemblage magnetite + orthopyroxene produces hematite + forsterite (Haggerty and Baker 1967). In our experiments, this texture forms at eruptive temperature, or at least at $\mathrm{T}>1,000{ }^{\circ} \mathrm{C}$, and is substantially absent in the low temperature range $\left(700-750{ }^{\circ} \mathrm{C}\right)$. This apparently contrasts with experiments of Haggerty and Baker (1967), who observed olivine exsolution at $600{ }^{\circ} \mathrm{C}$. We envisage that in our experiments, the run times are too short to allow the completion of this reaction confirming an obvious control of the kinetics and diffusivity on this process.

\section{General implications and conclusions}

Experiments have shown that the effects of reheating and exposure to variable redox conditions yield a number of diagnostic modifications strengthening the idea that the pyroclastic material, which resides in a crater area, can suffer significant changes to its primary features.

In addition, modifications occur even in a short time interval (minutes-hour) which is comparable with the duration of heating-cooling cycles affecting pyroclasts within the crater during weakly explosive activity.

Observed clast modifications are, on the whole, the same in all the investigated volcanic products, with only small differences related to the extent of undercooling/disequilibria that magmas experienced during ascent and before the eruption (e.g., LP magma at Stromboli). Our findings can be thus confidently extended to a large number of volcanoes with comparable mafic compositions.

Taking this in mind, our observations have direct implications on the interpretations of some features observed in volcanic deposits and can contribute to the understanding of volcanic processes occurring in an ideal crater environment (Fig. 1), which include a: (I) vent/s area, (II) inner walls and crater filling, and (III) cone flanks.

Vent area is a highly dynamic zone with the highest temperature and lowest atmospheric air entrainments (low redox). Experiments in the range 1,090-1,130 ${ }^{\circ} \mathrm{C}$ under SQT conditions evidence that in this environment effects of cycles of heating and cooling are hard to be recognized only on the basis of textural and compositional characterization. Vesicularity can eventually give some indications, but cannot be a reliable discriminating feature since bubblemelt separation can also be the results of the normal dynamics of the top of the magma column. Similarly, those clasts that during the explosions are exposed to the external atmosphere, reaching conditions similar to those characteristics of the OQT experiments, once fallen back in the vent, are immediately engulfed by the hot magma residing in the conduit. In this case, any evidence of exposure to high $\mathrm{fO}_{2}$ can be obliterated. Thus, on the whole, effects of high temperature syn-eruptive recycling of clasts become similar to the properties of magma residing in the shallowest part of the conduit. 
In the inner walls of the crater, we expect conditions of lower but variable temperatures and variable redox atmosphere as those simulated in experiments carried between 700 and $1,050{ }^{\circ} \mathrm{C}$. Experiments indicate that under these conditions highly crystallized clasts, with discolored surfaces, can develop on glassy starting material. These pyroclasts can also display subsolidus transformation of some minerals (e.g., olivine and or magnetite) and the formation of vapor phase on the external surface. Similar features can be diagnostic to distinguish material recycled within the crater area from even primary juvenile fragments derived from highly crystallized magma portion within the conduit.

Conditions expected along cone flanks strongly depend on the style of activity. In case of low energy activity (weak Strombolian activity), this area is characterized by low temperature $\left(\ll \mathrm{T}_{\mathrm{g}}\right)$ and modifications of pyroclasts can be only related to exposure to volcanic gases (Spadaro et al. 2002). These conditions cannot be discussed on the basis of our experiments. In case of high energy eruptions (e.g., Violent Strombolian or Fire Fountains), fall and accumulation of hot ejecta can induce rapid heating of the substratum with associate sintering, agglutination and coalescence of pyroclasts (Sumner et al. 2005; Bertagnini et al. 2011).

Experiments carried out at temperature $>1,000{ }^{\circ} \mathrm{C}$ reproduce the thermal and redox conditions of these processes. Results indicate that reddening of the clast surface takes place accompanied by variable groundmass crystallization and significant change in glass composition. In the high temperature range $\left(>1,050{ }^{\circ} \mathrm{C}\right)$, also welding of portions not exposed to the air can develop, until the complete remobilization and flowing of the heated material. The effects of the sintering and melt remobilization observed in our experiments partially reproduce mechanism of formation of agglutinated spatter deposit and rootless lava flows resulting from rapid accumulation of hot material on cone flanks.

In conclusion, this paper may provide a tool with good potential for useful reconstructions of the complete clasts history before the final emplacement and of the whole eruption dynamics.

Comparison of the textural and morphological features of natural samples from real deposits with the main features observed in experiments will help to identify a set of diagnostic elements useful to interpret nature and origin of different tephra components.

\section{Acknowledgments}

We sincerely thank Hans Keppler, Kelly Russell and an anonymous reviewer for constructive criticism and suggestions. We are indebted to Andrea Cavallo (INGV-Rome) and Lucia Miraglia (INGV-Catania) for assistance in EMP and SEM analysis and to Patrizia Pantani (INGV-Pisa) for graphic assistance. We are also grateful to Patrizia Landi (INGV-Pisa) for providing Stromboli HP sample. Work was founded by MIUR project: "Advancing Interdisciplinary Research Platform on Volcanoes and Earthquakes" - (AIRPLANE) and by MIUR-PRIN 2008 AshErupt- UR 20083MC8W2_003. 


\section{References}

Allard P, Aiuppa A, Burton M, Caltabiano T, Federico C, Salerno G, La Spina A (2008) Crater gas emissions and the magma feeding system of Stromboli volcano. In: Calvari S, Inguaggiato S, Puglisi G, Ripepe M, Rosi M (eds) The Stromboli Volcano: an integrated study of the 2002-2003 eruption, vol 182. American Geophysical Union, Washington, pp 6580

Asimow P, Ghiorso M (1998) Algorithmic modifications extending MELTS to calculate subsolidus phase relations. Am Mineral 83:1127-1132

Bertagnini A, Métrich N, Francalanci L, Landi P, Tommasini S, Conticelli S. (2008)

Volcanology and magma geochemistry of the present-day activity: constraints on the feeding system. In: Calvari S, Inguaggiato S, Puglisi G, Ripepe M, Rosi M (eds) The Stromboli Volcano: an integrated study of the 2002-2003 eruption, vol 182. American Geophysical Union, Geophysical Monograph Series, Washington, pp 19-37

Bertagnini A, Di Roberto A, Pompilio M (2011) Paroxysmal activity at Stromboli: lessons from the past. Bull Volcanol 73:1229-1243

Bouhifd MA, Richet P, Besson P, Roskosz M, Ingrin J (2004) Redox state, microstructure and viscosity of a partially crystallized basalt melt. Earth Planet Sci Lett 218:31-44

Burkhard D (2001) Crystallization and oxidation of Kilauea basalt glass: processes during reheating experiments. J Petrol 42:507-527

Burkhard DJ (2002) Kinetics of crystallization: example of micro-crystallization in basalt lava. Contrib Mineral Petrol 142:724-737

Calvari S, Coltelli M, Neri M, Pompilio M, Scribano V (1994) The 1991-1993 Etna eruption: chronology and lava flow-field evolution. Acta Vulcanol 1:1-14

Carignan J, Hild P, Mevelle G, Morel J, Yeghicheyan D (2001) Routine analyses of trace elements in geological samples using flow injection and low pressure on-line liquid chromatography coupled to ICP-MS: a study of geochemical reference materials BR, DR-N, UB-N, AN-G and GH. Geostandard Newslett 25(2-3):187-198

Carveni P, Romano R, Caltabiano T, Grasso MF, Gresta S (1994) The exceptional explosive activity of 5 January 1990 at the SE-Crater of Mt. Etna volcano (Sicily). Boll Soc Geol Ital 113:613-631

Cioni R, Marianelli P, Santacroce R (1999) Temperature of Vesuvius magmas. Geology $27: 443-446$

Cioni R, D'Oriano C, Bertagnini A (2008) Fingerprinting ash deposits of small scale eruptions by their physical and textural features. J Volcanol Geotherm Res 177:277-287 
Cioni R, Bertagnini A, D’Oriano C, Pompilio M (2010) Past and present mid-intensity explosive eruptions of Italian volcanoes and their impact on human activity. J Virtual Explorer. doi:10.3809/jvirtex.2009.00229

Cooper R, Fanselow J, Poker D (1996) The mechanism of oxidation of a basaltic glass: chemical diffusion of network-modifying cations. Geochim Cosmochim Acta 60:3253-3265

Corsaro R, Pompilio M (2004) Magma dynamics in the shallow plumbing system of Mt. Etna as recorded by compositional variations in volcanics of recent summit activity (1995-1999). J Volcanol Geotherm Res 137:55-71

Corsaro RA, Miraglia L, Pompilio M (2007) Petrologic evidence of a complex plumbing system feeding the July-August 2001 eruption of Mt. Etna, Sicily, Italy. Bull Volcanol 69:401-421

Devine J, Gardner J, Brack H, Layne GD, Rutherford MJ (1995) Comparison of microanalytical methods for estimating $\mathrm{H} 2 \mathrm{O}$ contents of silicic volcanic glasses. Am Mineral 80:319-328

Di Carlo I, Pichavant M, Rotolo SG, Scaillet B (2006) Experimental crystallization of a highK arc basalt: the golden pumice, Stromboli volcano (Italy). J Petrol 47:1317

Dingwell D, Virgo D (1987) The effect of oxidation state on the viscosity of melts in the system $\mathrm{Na}_{2} \mathrm{O}-\mathrm{FeO}-\mathrm{Fe}_{2} \mathrm{O}_{3}-\mathrm{SiO}_{2}$. Geochim Cosmochim Acta 51:195-205

Dingwell D, Webb S (1990) Relaxation in silicate melts. Eur J Mineral 2:427-449

D'Oriano C, Cioni R, Bertagnini A, Andronico D, Cole PD (2011) Dynamics of ashdominated eruptions at Vesuvius: the post-512 AD AS1a event. Bull Volcanol 73:699-715

Francalanci L, Bertagnini A, Metrich N et al. (2008) Mineralogical, geochemical, and isotopic characteristics of the ejecta from the 5 April 2003 paroxysm at Stromboli, Italy: inferences on the preeruptive magma dynamics. In: Calvari S, Inguaggiato S, Puglisi G et al. (eds) The Stromboli Volcano: an integrated study of the 2002-2003 eruption, vol 182. American Geophysical Union, Geophysical Monograph Series, Washington, pp 331-345

Ghiorso M, Carmichael I (1985) Chemical mass transfer in magmatic processes. Contrib Mineral Petrol 90:121-141

Giordano D, Nichols A, Dingwell D (2005) Glass transition temperatures of natural hydrous melts: a relationship with shear viscosity and implications for the welding process. J Volcanol Geotherm Res 142:105-118

Giordano D, Russell J, Dingwell D (2008) Viscosity of magmatic liquids: a model. Earth Planet Sci Lett 271:123-134

Grunder A, Russell JK (2005) Welding processes in volcanology: insights from field, experimental, and modeling studies. J Volcanol Geotherm Res 142:1-9

Haggerty SE (1991) Oxide textures; a mini-atlas. Rev Mineral 25:129-192 
Haggerty SE, Baker I (1967) The alteration of olivine in basaltic and associated lavas. Contrib Mineral Petrol 16:233-257

Hamilton D, Burnham C, Osborn E (1964) The solubility of water and effects of oxygen fugacity and water content on crystallization in mafic magmas. J Petrol 5:21-39

Hammer $\mathbf{J}$ (2006) Influence of $\mathrm{fO}_{2}$ and cooling rate on the kinetics and energetics of Fe-rich basalt crystallization. Earth Planet Sci Lett 248:618-637

Hammer JE (2008) Experimental studies of the kinetics and energetics of magma crystallization. Rev Mineral Geochem 69:9-59

Kennedy BM, Jellinek AM, Russel JK, Nichols ARL, Vigouroux N (2010) Time-and temperature-dependent conduit wall porosity: a key control on degassing and explosivity at Tarawera volcano, New Zealand. Earth Planet Sci Lett 299:126-137

Landi P, Marchetti E, La Felice S, Ripepe M, Rosi M (2011) Integrated petrochemical and geophysical data reveals thermal distribution of the feeding conduits at Stromboli volcano, Italy. Geophys Res Lett. doi:10.1029/2010GL046296

Le Bas M, Le Maitre R, Streckeisen A, Zanettin B (1986) A chemical classification of volcanic rocks based on the total alkali-silica diagram. J Petrol 27:745-750

Lofgren G (1974) An experimental study of plagioclase crystal morphology: isothermal crystallization. Am J Sci 274:245-273

Métrich N, Rutherford M (1998) Low pressure crystallization paths of $\mathrm{H}_{2} \mathrm{O}$-saturated basalticHawaiitic melts from Mt Etna: implications for open-system degassing of basaltic volcanoes. Geochim Cosmochim Acta 62:1195-1205

Métrich N, Bertagnini A, Landi P, Rosi M (2001) Crystallization driven by decompression and water loss at Stromboli volcano (Aeolian Islands, Italy). J Petrol 42:1471-1490

Métrich N, Bertagnini A, Landi P, Rosi M, Belhadj O (2005) Triggering mechanism at the origin of paroxysms at Stromboli (Aeolian Archipelago, Italy): the 5 April 2003 eruption. Geophys Res Lett 32:1-4

Métrich N, Bertagnini A, Di Muro A (2010) Conditions of magma storage, degassing and ascent at stromboli: new insights into the volcano plumbing system with inferences on the eruptive dynamics. J Petrol 51:603-626

Moriizumi M, Nakashima S, Okumura S, Yamanoi Y (2008) Color-change processes of a Plinian pumice and experimental constraints of color-change kinetics in air of an obsidian. Bull Volcanol 71:1-13

Mysen B (1983) The structure of silicate melts. Annu Rev Earth Planet Sci 11:75-97

Peccerillo A, Taylor S (1976) Geochemistry of Eocene calc-alkaline volcanic rocks from Kastamonu area, Northern Turkey. Contrib Mineral Petrol 58:63-81 
Pompilio M, Trigila R, Zanon V (1998) Melting experiments on Etnean lavas: the calibration of an empirical geothermometer to estimate the eruptive temperature. Acta Vulcanol 10:1-9 Pompilio M, Bertagnini A, Métrich N (2012) Geochemical heterogeneities and dynamics of magmas within the plumbing system of a persistently active volcano: evidence from Stromboli. Bull Volcanol 74:881-894

Quane SL, Russell JK (2005) Welding: insights from high-temperature analogue experiments. J Volcanol Geotherm Res 142:67-87

Quane SL, Russell JK, Friedlander EA (2009) Time scales of compaction in volcanic systems. Geology 37:471-474

Raghavan V (2006) Cu-Fe-S (Copper-Iron-Sulfur). J Phase Equilib Diffus 27:290-291

Rosi M, Bertagnini A, Hanis A, Pioli L, Pistolesi M, Ripepe M (2006) A case history of paroxysmal explosion at Stromboli: timing and dynamics of the April 5, 2003 event. Earth Planet Sci Lett 243:594-606

Sack R, Carmichael I, Rivers M, Ghiorso M (1981) Ferric-ferrous equilibria in natural silicate liquids at 1 bar. Contrib Mineral Petrol 75:369-376

Scaillet B, Pichavant M, Cioni R (2008) Upward migration of Vesuvius magma chamber over the past 20,000 years. Nature 455:216-219

Spadaro F, Lefèvre R, Ausset P (2002) Experimental rapid alteration of basaltic glass: implications for the origins of atmospheric particulates. Geology 30:671-674

Stimac J, Hickmott D, Abell R, Larocque ACL, Broxton D, Gardner J, Chipera S, Wolff J, Gauerke E (1996) Redistribution of $\mathrm{Pb}$ and other volatile trace metals during eruption, devitrification, and vapor-phase crystallization of the Bandelier tuff, New Mexico. J Volcanol Geotherm Res 73:245-266

Sumner J, Blake S, Matela R, Wolff J (2005) Spatter. J Volcanol Geotherm Res 142:49-65

Tait S, Thomas R, Gardner J, Jaupart C (1998) Constraints on cooling rates and permeabilities of pumice in an explosive eruption jet from colour and magnetic mineralogy. J Volcanol Geotherm Res 86:79-91 